\title{
The Palaeolithic occupation of southern Alentejo: the Sado River Drainage Survey
}

\section{La ocupación paleolítica del Alentejo meridional: investigación en la cuenca del río Sado}

\author{
Ariane Burke (*) \\ Liliane Meignen $(* *)$ \\ Michael Bisson $(* * *)$ \\ Nuno Pimentel $(* * * *)$ \\ Virginia Henriques $(* * * * *)$ \\ César Andrade (****)
}

\author{
Maria da Conceição Freitas $(* * * *)$ \\ Masa Kageyama $(* * * * * *)$ \\ William Fletcher $(* * * * * * *)$ \\ Carla Parslow $(* * * * * * * *)$ \\ Dario Guiducci (*)
}

\begin{abstract}
The Sado River Drainage Survey project (2004-2008) was designed to fill a significant gap in our knowledge of the prehistory of Portugal. Southern Alentejo constitutes nearly one third of the total land mass of continental Portugal, but has received comparatively little attention from Palaeolithic archaeologists. Practically nothing was known about the prehistory of the Sado River basin, which includes the southern Alentejo plain, before now. The results of the Sado River Drainage Survey (SRDS) indicate that the Sado River basin was likely occupied at low population densities during the Middle Palaeolithic. There is some evidence for a Lower Palaeolithic presence but little or no evidence of an Upper Palaeolithic occupation. The emerging pattern suggests either an occupational hiatus or a major shift in settlement pattern towards the end of the Middle Palaeolithic. Possible explanations for this pattern, including aridification driven by climate change, are explored here.
\end{abstract}

\section{RESUMEN}

El proyecto de prospección de la cuenca del río Sado (SRDS), llevado a cabo entre el 2004 y el 2008, se diseñó

(*) Dept. d'anthropologie, Université de Montréal, C.P. 6128, Succursale Centre-Ville. Montreal. QC. Canada H3C 3J7. E-mail: a.burke@umontreal.ca; daguiducci@gmail.com

(**) Université Nice Sophia Antipolis. Campus Saint-Jean-d'Angély. SJA3 - CEPAM - UMR 6130 CNRS. 24, avenue des Diables Bleus. 06357 Nice Cedex. France. E-mail: liliane.meignen@cepam.cnrs.fr

(***) Dept. of Anthropology, McGill University. Leacock Building, 855 Sherbrooke Street West, Montreal. Quebec. Canada H3A 2T7. E-mail: michael.bisson@mcgill.ca

$(* * * *)$ Dept. de Geologia, Faculdade de Ciências da Universidade de Lisboa, Bloco C6, 3..$^{\circ}$ piso, Campo Grande. 1749-016 Lisboa. Portugal. E-mail: Pimentel@fc.ul.pt candrade@fc.ul.pt, cfreitas@fc.ul.pt para suplir la carencia de información concerniente al conocimiento actual de la Prehistoria de Portugal. Aunque la cuenca del río Sado conforma casi un tercio de la superficie continental de Portugal, aún no había recibido la debida atención para el Paleolitico. Antes de este proyecto, prácticamente nada se conocía acerca de la Prehistoria de dicha cuenca, incluyendo la llanura de Alentejo. Nuestros resultados indican una baja densidad de población durante el Paleolítico Medio, rastro de ocupaciones del Paleolítico Inferior y casi ninguna evidencia de ocupaciones asociadas al Paleolítico Reciente. A partir de los datos obtenidos, se desprende un modelo en el que se evidencia que, hacia finales del Paleolítico Medio, hubo una discontinuidad en la ocupación, probablemente asociada a cambios climáticos o del uso del territorio.

Key words: Middle Palaeolithic; Neanderthal; Land-use patterns; Portugal; Alentejo; Sado River Basin; Paleoclimate.

Palabras clave: Paleolítico medio; Neandertal; Patrones de usos del suelo; Portugal; Alentejo; Sado; Paleoclima.

$(* * * * *)$ Geosciences Dept. Université de Évora, Rue Romão Ramalho, 59 7000-671 Évora. Portugal. E-mail: virginia@uevora.pt

$(* * * * *)$ Laboratoire des Sciences du Climat et de l'Environnement, LSCE/IPSL - CEA-CNRS-UVSQ, CE Saclay, l'Orme des Merisiers, batiment 701, 91191 Gif-sur-Yvette Cedex France. E-mail: Masa.Kageyama@1sce.ipsl.fr

$(* * * * * *)$ Ecole Pratique des Hautes Etudes, UMR 5805 CNRS EPOC, Université Bordeaux 1. 33405 Talence. France. E-mail: W.Fletcher@em.uni-frankfurt.de

$(* * * * * * *)$ Golder Associates Ltd. 2390 Argentia Road. Mississauga, Ontario. Canada L5N 5Z7. E-mail:

Carla_Parslow@golder.com

Recibido: 26-III-2010; aceptado: 15-VII-2010. 


\section{INTRODUCTION: THE IBERIAN PALAEOLITHIC}

The archaeological record of the Iberian Peninsula contains several important landmarks that guide our current understanding of the Palaeolithic settlement of Europe. Discoveries at Atapuerca (Burgos, Spain) definitively proved that hominids were present in Iberia before the Middle Pleistocene (Falguères et al. 1999), thus putting to rest a long-standing debate concerning the timing of the initial colonisation of Europe (Roebroeks et al. 1992). Atapuerca also provided evidence for the existence of a new species, Homo antecessor (Aguirre y Carbonell 2001; Carbonell et al. 2008; Carbonell et al. 1995; Bermúdez de Castro et al. 1997), a plausible ancestor of the Neanderthals (Bermúdez de Castro et al. 2004; Bermúdez de Castro et al. 1997). Southern Iberia (including Portugal, southern Spain and Gibraltar) has also yielded evidence for the persistence of a Neanderthal population until as recently as $30 \mathrm{Kyrs}$ B.P., if not younger (Finlayson et al. 2006; Villaverde et al. 1998; Zilhão 1998). The Iberian Peninsula, therefore, probably forms part of the core range of the Neanderthals (Serangeli and Bolus 2008), towards which they eventually contracted after a period of expansion. Clearly, understanding the pattern of biological and cultural succession in the Iberian Peninsula is a key to understanding the process of emergence and extinction of the Neanderthals in Europe.

Despite their geographical proximity, there do not appear to have been any direct cultural or biological exchanges between North Africa and the Iberian Peninsula during the Middle and Late Pleistocene, at least until the terminal Palaeolithic (Hublin 1992; Straus 2001). The archaeological record of Iberia could therefore be expected to follow the general pattern of biological and cultural succession observed in Western Europe. But, whereas Neanderthals were eventually replaced by modern humans (but see Duarte et al. 1999 contra Tattersall and Schwartz 1999), the exact timing of the succession is difficult to establish. This is partly because cultural succession in the Iberian Peninsula differs significantly from the expected pattern (Bicho 2000; Villaverde et al. 1998). Early Upper Palaeolithic (Aurignacian) industries are sparsely represented in Iberia and there is a noticeable delay in the timing of their appearance relative to Western Europe (Bicho
2000; Villaverde et al. 1998; Zilhão 1997; Zilhão and Villaverde 2008). This delay is correlated with the persistence of comparatively late Mousterian industries. To complicate matters even further, in Northwestern Spain (Cantabria and the Basque country) a half dozen sites with continuous records of occupation spanning the Middle to Upper Palaeolithic cultural succession contain what some researchers interpret as evidence for in situ development of an Aurignacian industry (Arrizabalaga et al. 2003; Cabrera et al. 2001; Maíllo Fernández et al. 2004) (for a different perspective on the significance of this development, see Straus 1997; Villaverde et al. 1998).

The archaeological record of Portugal is a microcosm of the Iberian record, with many of the same debates being played out, albeit on a smaller scale. The debate concerning the existence of an early Aurignacian in Portugal (Bicho 2000; Zilhão et al. 2010; Zilhão et al. 1995), for example, is part of the larger debate over the chronology and distribution of Aurignacian industries in the Iberian Peninsula. The early Upper Palaeolithic is only represented by a handful of assemblages in Central Portugal that could be either late Aurignacian or early Gravettian in age (Aubry 2008; Aubry et al. 2006). In southern Portugal (in the Algarve, for example) the Gravettian directly succeeds the Mousterian (Bicho 2000; Straus et al. 2000). A similar pattern is observable in Mediterranean Spain (Villaverde et al. 1998). These departures from the "expected" pattern of cultural succession (based on the archaeological record of Southwestern France) have implications for the timing of the biological succession in the Iberian Peninsula (Aubry 2008; Straus 1997; Zilhão 1998).

\section{THE STUDY REGION}

\subsection{A brief history of archaeological investigation in Southern Alentejo}

The Sado River Basin (Fig. 1) is located in the southern part of Alentejo province (in the districts of Setúbal and Beja). Although little Palaeolithic research had been conducted in the Sado Basin prior to this study, its archaeological potential was considered to be good on the basis of evidence from adjacent regions. The Setúbal Peninsula (including the Serra Arrábida), on the 


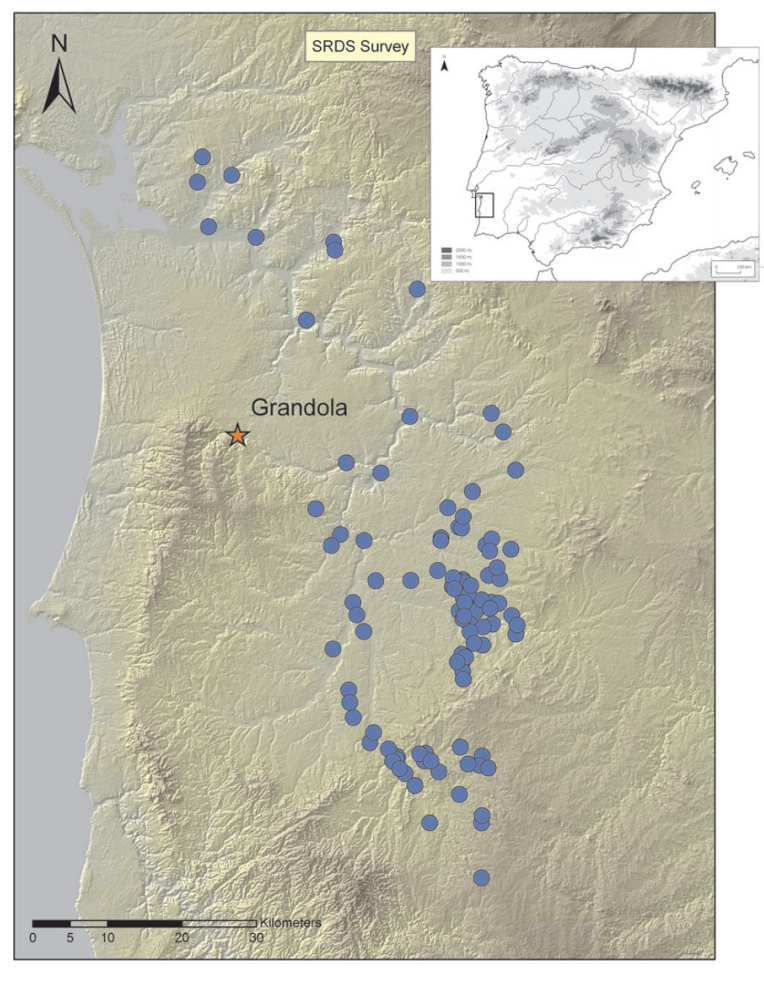

Fig. 1. The SRDS study region showing survey locations.

northern boundary of the Sado River Basin, has been the focus of archaeological interest since the beginning of the $19^{\text {th }}$ century. This activity has resulted in the discovery several Palaeolithic sites including one of only three stratified, Middle Palaeolithic sites in Portugal that have yielded Neanderthal remains - the site of Figueira Brava (Antunes 1990-1991, 2000; Antunes and Cunha 1992). Another well-known Palaeolithic site in the vicinity of the study area, Gruta do Escoural (Montemor o Novo, Central Alentejo), contains a rare example of Portuguese Upper Palaeolithic cave art, as well as evidence for Middle Palaeolithic occupation (Araújo and Lejeune 1995). Surveys of the Tagus River Basin (Almeida 2003; Mozzi et al. 2000; Raposo 2005) and in Northern Alentejo (Almeida et al. 2006; Almeida 2003) have also yielded Palaeolithic finds.

The littoral zone of southern Alentejo was first surveyed by Breuil and Zbyszewski (1949), and associates (Breuil et al. 1943). Viana (1943, 1945, 1946, 1947; Viana and Zbyszewski 1949, 1952 ) was very active during the mid $20^{\text {th }}$ Century in Alentejo province. More recently, archaeological surveys of the Guadiana River Basin have uncovered several open-air, Palaeolithic localities (Araújo and Almeida 2003; Almeida et al. 2002). In the target region itself, impact studies associated with the construction of a major highway (the A2, connecting Lisbon to the Algarve), a gas pipeline (from Setúbal to Sines) and various hydrological projects have been conducted under the supervision of the Instituto de Gestão do Património Arquitectónico e Arqueológico $(I G E S P A R)$. Little evidence for the $\mathrm{Pa}$ laeolithic occupation of the Sado River Basin existed prior to this research, however, consisting mainly of isolated surface finds. Only three sites attributed to the Palaeolithic were recorded in IGESPAR's archaeological database (Endovelico) including the open-air sites of Barrosinha I, Quinta da Baixa (both in the Concelho of Alcácer do Sal) and Migueis I (Concelho of Ourique).

\subsection{Geographical and geological setting}

The Sado River drainage system, an area measuring $8341 \mathrm{~km}^{2}$, is bordered to the north by the Tagus river basin and by the Guadiana and the Mira river basins to the south and east, respectively (Fig. 1). The focus of this research was the Sado River basin excluding the estuary, an area of $7692 \mathrm{~km}^{2}$ with a mean altitude of $127 \mathrm{~m}$ asl. The Sado River is approximately $180 \mathrm{~km}$, initially flowing in a northwesterly direction from its source in the Serra da Vigia (230 m asl) to entrance at the Cenozoic Sado Basin, then northerly along this basin until its confluence with the Odivelas River, where it changes its course and flows in a more westerly direction towards the Atlantic.

The topography of the study region is heavily influenced by tectonic processes. A series of fault systems cross the Sado River Basin, including the Grândola fault, oriented WSW-ESE, and the Messejana fault, oriented NE-SW. Subsidence of the Sado Basin, relative to the Paleozoic areas further South and the formation of the Grândola horst, both occured at the beginning of the Quaternary (Pimentel and Azevedo 1991) (1) resulted in distinctly different sedimentary histories in the northern and southern halves of the Sado drainage system. The SRDS survey concentrated on the southern part of the Sado River Basin for reasons fully explained below.

(1) Pimentel, N. L. 1997: O Terciário da Bacia do Sado, sedimentologia e análise tectono.sedimentar. $\mathrm{PhD}$ Thesis, Univ. Lisboa. 
The northern part of the Sado drainage system, from Grândola to the Sado river estuary, forms part of the littoral platform; a thick tertiary fill is capped by Pliocene fluvial sands, easily loosened by pedogenesis and remobilised by aeolian processes. The southern part, from Grândola to the Serra da Vigia, includes two different areas: the Cenozoic Sado Basin area, with approximately the same geological characteristics, and the Paleozoic basement area (2). In the Basin area, outcropping sediments are mostly Pliocene fluvial deposits, locally capped by coarse Raña deposits (Pimentel and Azevedo 1991) (3). Underlying these fluvial sands, transitional and marine Miocene sediments may outcrop, comprising fine sands, clays and tabular carbonates. Poorly developed, well-drained sand-rich soils formed on fluvial sands, exhibiting low erosion rates except along the banks of the Sado and its main tributaries.

The current drainage system began forming during the Pleistocene, after the disruption of the Pliocene fluvial network by a climatic crisis testified by the presence of aridity-related alluvial fan Raña deposits. Quaternary fluvial incision, related to differential tectonic up-lift of the region, resulted in the formation of Quaternary terraces along the Sado and its affluents (Schermerhorn et al. 1987). In the northern sector however, due to the abundance of sandy colluviums, fluvial terraces are difficult to identify and a single series of terraces of unknown age is indicated (4). South of Grândola, the Sado River developed large alluvial plains and presents distinct terraces along most of its course. In the Sado Basin area north of Panoias, only one lower terrace $(+15 \mathrm{~m})$ is present, whereas further south, incised into the Palaeozoic basement, two terraces $(+15 \mathrm{~m}$ and $+45 \mathrm{~m})$ are recognized (Pimentel and Azevedo 1991) (5). This situation has been interpreted as the result of neotectonic movements along the borders of the Sado Basin (the Messejana fault) occuring between the formation times of the two terraces.

The most recent change in the sedimentary history of the Sado River and its tributaries results from human activity. A shift from traditional farming practices to large-scale cultivation of

(2) Pimentel, N. 1989: Evolução plio-quaternaria do Baixo Alentejo ocidental. Departamento de Geologia da Faculdade de Ciências de Lisboa. Lisboa.

(3) See note 2.

(4) See note 2.

(5) See note 2. wheat in the $19^{\text {th }}$ century, inspired by government policy, caused widespread erosion of soils and the subsequent silting up of the Sado and its tributaries, particularly in the northern part of the study region (Schermerhorn et al. 1987).

\subsection{Seasonal lakes in the interfluves (the planalto)}

A series of shallow depressions, barely visible in the landscape when dry due to the smoothness of the local relief, sometimes indicated on the topographical maps or visible in aerial photographs, punctuate the culminating surface. These features may represent relicts of older and more numerous depressions existing in the vast alluvial plain that formed during the Plio-Pleistocene on the planalto during the initial organization of the present-day hydrographical network. The depressions form small, seasonal lakes (locally named lagoas or lagoinhas) that are well-represented in the southern part of the Sado Basin, generally located in interfluves where they have been preserved from erosion and may occasionally form sinks for small endorreic and poorly organized streams. Until fairly recently, rice was grown in some of these depressions. During the 1950s a system of open canals joined several of these small lagoas. More recently, many of the smaller depressions have been levelled by the plough or land filled. Recent human intervention has thus contributed to smooth the natural morphological features. The infilling sequence of Lagoa de Gasparões, which was studied by us in an attempt to understand the formation of these small depressions, consists of about $2 \mathrm{~m}$ of poorly sorted sandy mud disturbed by $40 \mathrm{~cm}$ of ferruginous muddy sand with abundant centimetric to milimetric quartzite and jasper pebbles, as well as $\mathrm{Fe} / \mathrm{Mn}$ pisoliths (from a depth of $1.30 \mathrm{~m}$ to 1.70 $\mathrm{m}$ below surface). Organic matter is absent, with the exception of the top soil. Similar lacustrine deposits identified around Ferreira do Alentejo and Figueira de Cavaleiros, in the south of the study region, are attributed to the Pleistocene (Oliveira 1984).

\subsection{Raw material sources}

Sources of raw material suitable for Palaeolithic tool-making are rather limited in the target

T. P., 68, N. ${ }^{\circ} 1$, enero-junio 2011, pp. 25-49, ISSN: 0082-5638 doi: $10.3989 /$ tp.2011.11057 
region. The nearest sources of flint occur along the littoral platform, along the Serra Arrábida and in the vicinity of Alcácer do Sal. Jasper, therefore, is the most abundant, good quality local raw material. Jasper outcrops occurs on the margins of the basin and in the southern part of the study region. Jasper also occurs secondarily as cobbles along many of the rivers, especially along the right bank of the Sado River. Quartzite outcrops are located near Odivelas and quartzite would have been available in secondary deposits along the Canhestros River. Quartz veins occur throughout the region and quartz cobbles are secondarily deposited along most of the river terraces. Other potentially useful raw materials are also encountered in secondary contexts as cobbles on river terraces, including greywacke and sandstone.

\section{SURVEY DESIGN}

The survey took place during the course of four consecutive years (2005 to 2008) with field seasons lasting between four to six weeks. In total, 112 survey locations were examined (Fig. 1). The study region is a sedimentary basin containing marine deposits formed initially during the Miocene, overlain by Plio-Pleistocene sediments deposited on the broad erosion surface that formed as the sea retreated. These planalto deposits were in turn dissected and reworked by the river system that began forming during the Pleistocene. Much of the Sado River Basin, including the planalto where cereal production dominates, is open and easily surveyed. The sedimentological history of the Basin has a significant impact on the landscape, however, which affects survey design.

In the northern half of the target region (north of Grândola), fine, sandy sediments of variable age are constantly being remobilized and it is difficult to distinguish, much less date, the ancient landscape. South of Grândola, however, two river terraces formed during the Quaternary are visible along the Sado River, and sediments attributed to the Plio-Pleistocene on the geological maps are readily distinguishable on the planalto. As a result, survey effort was largely concentrated in the southern half of the study region (south of Grândola) and much of the discussion that follows will focus on this sub-region.
We systematically surveyed the mapped quaternary terraces along the Sado River and randomly selected terraces of unknown age. A fourstage terrace system (Günz, Mindel, Riss and Würm stages) initially proposed for the Tagus River by Zbyszewski is used as a basis for the mapping other Portuguese river systems (Mozzi et al. 2000). Along the Sado River two terraces, Q3 and Q4, have been mapped; according to this chronological scheme the Q3 terraces are considered to date to the Riss, the Q4 terraces are dated to the Würm. More recent work on river terraces in Portugal has revealed a much more complex situation, however (Bridgland et al. 2006) and the chronological attribution of the terraces along the Sado River is uncertain (Pimentel and Azevedo 1991) (6). Zbyszewski (1971: 14-15) associates the Upper Sado River Terrace with the Acheulean cultural period and the Lower Terrace with the Mousterian; our results (below) are compatible with this proposed chronology.

We also systematically investigated the lacustrine features and deposits (lagoas and lagoinhas) scattered on the surface of the planalto, mainly in the southern half of the study region. Similar features in the Algarve yielded archaeological materials, e.g., at Lagoa do Bordal (Ferring et al. 2000; Bicho 2004). Finally, we systematically surveyed raw material sources wherever primary contexts could be identified; these mostly consisted of jasper outcrops associated with the Iberian Pyrite belt formation. Jasper outcrops were located using geological maps supplied to us by Dr. J. Matos, INETI (Beja). Most of the outcrops occur in the south and are associated with manganese deposits, many of which were mined during the course of the $20^{\text {th }}$ Century.

\subsection{Field methodology}

Survey members worked in teams of 3-5 people walking in parallel transects, equipped with WAAS enabled GPS units (Garmin(C eTrek). GPS accuracy varied within the study region but 2-3 m accuracy was common. With some exceptions, artefacts were collected during the survey and their geographical coordinates stored in the GIS database (7). The SRDS lithic collection is

(6) See note 2.

(7) In 2008 some artifacts were mapped at Mina do Paço, but not collected. 
now curated at the Museu Municipal de Aljustrel. In addition to field surveys, $1 \times 1 \mathrm{~m}$ test pits were excavated at four locations: Gasparões, Mina do Paço, Moínhos II and Vermelha. Limited coring tests were also performed using a gas-powered, hand-held vibra-corer in 2008, with the help of $\mathrm{N}$. Almeida (IGESPAR), at: Cabeça do Marco, Rio Moínhos and Mudança. In every case, sterile sediments or bedrock occurred just below the plough-zone. Artefacts from the test pits are included in the overall analysis (see below).

In addition to field surveys, a series of $1 \times 1 \mathrm{~m}$ test pits were excavated at four locations: Gasparões, Mina do Paço, Moínhos II and Vermelha. The test pits were hand-excavated in $10 \mathrm{~cm}$, arbitrary spits and dry-sieved using $2 \mathrm{~mm}$ mesh. Testing ceased when either bedrock or archaeologically sterile sediments were reached. In every case, this occurred just below the plough-zone. Artefacts from the test pits are included in the overall analysis (see below). Limited coring tests were also performed using a gas-powered, handheld vibra-corer in 2008, with the help of N. Almeida (IGESPAR), at: Cabeça do Marco, Rio Moínhos and Mudança.

Survey locations are designated as "significant" on the basis of a combination of lithic abundance, lithic density, and the presence of diagnostics. Assemblages with more than $\mathrm{N}=30$ artefacts are considered "of interest". Lithic density was assessed using the kernel density function in arcGIS. The search radius established for the function was set at $10 \mathrm{~m}$ and the cut-off points were established as follows: $0-0.01 ; 0.01-0.02$; 0.02-0.1; 0.1-1.

Kernel values of up to 0.01 are essentially single finds; values between 0.01-0.02 are considered diffuse; values of 0.02-0.1 are considered spatially discrete; values $>0.1$ are discrete and relatively dense. Larger lithic assemblages $(\mathrm{N}>100)$ with kernel values of 0.02 or higher are designated as sites. Medium-sized assemblages $(\mathrm{N}=30-100)$ with kernel values $>0.02$ are designated as localities. The term lithic scatter is reserved for smaller assemblages $(\mathrm{N}<30)$ with low density values, which may or may not contain chronologically diagnostic material. In the final analysis, the spatial distribution and chronological attribution of all sites, localities, and lithic scatters with chronologically diagnostic material will be considered.

\subsection{Results}

A total of $\mathrm{N}=1960$ lithic artefacts were recovered from 83 different locations (Fig. 2). No faunal remains were encountered (hardly surprising given the geological and sedimentary context). Ceramics were recorded but not collected.

Lithic remains were analysed by LM and MB. The spatial coordinates, raw material, type (cortical flake, normal flake, Levallois flake, retouched tool, core, other), size class $(1=<2 \mathrm{~cm} ; 2=2-4$ $\mathrm{cm} ; 3=4-6 \mathrm{~cm} ; 4=>6 \mathrm{~cm}$ ), degree of exploitation of cores, and finally, chronological attribution (where possible) were all recorded. Lithic artefacts considered diagnostic of the Middle $\mathrm{Pa}$ laeolithic include Levallois cores, flakes and tools on Levallois blanks, as well as centripetal cores, provided they are demonstrably of the recurrent, Levallois type. Centripetal cores with preferential surface exploitation are considered "probable" Middle Palaeolithic pieces, as are discoid cores, pseudo-Levallois products and some bifacial pieces (such as encountered at Moínhos 1 and 2, below). Bifaces are considered diagnostic

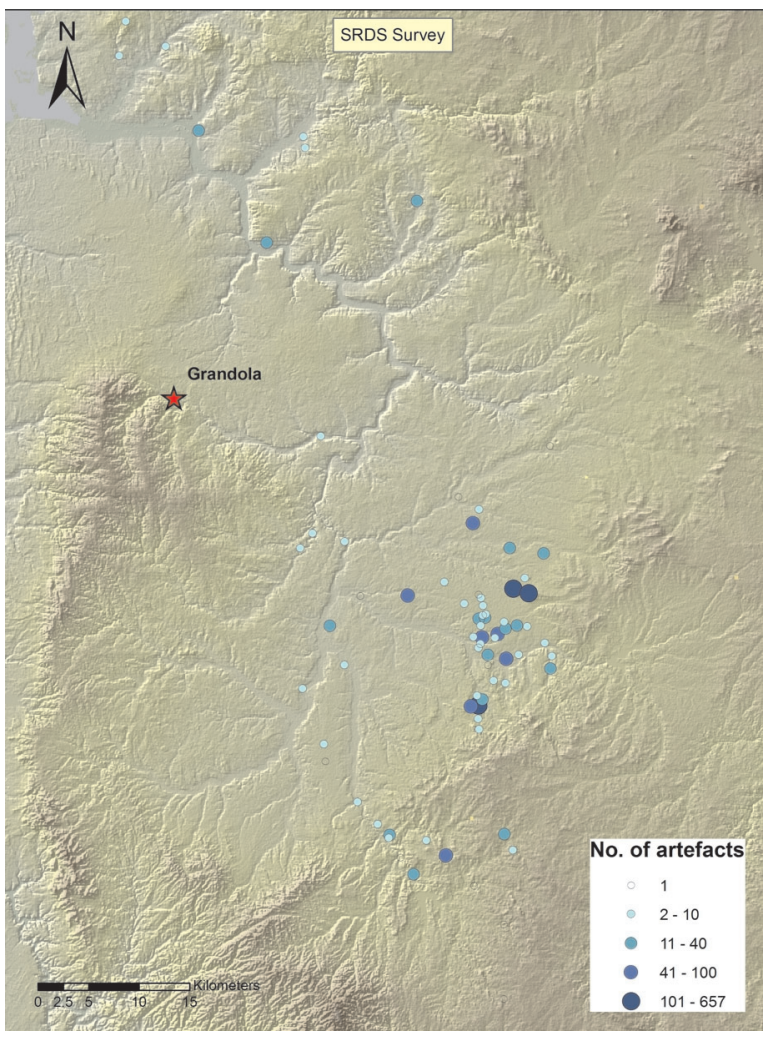

Fig. 2. Lithic artefacts recovered by the SRDS survey. 
of the Acheulean (Lower Palaeolithic). Surface condition was also noted (abrasion, polish, encrustations) and used in the final analysis to assess the homogeneity of each series. Laminar products are considered diagnostic of Upper $\mathrm{Pa}$ laeolithic, late Palaeolithic or Protohistoric periods according to their characteristics. Normal flakes and cortical flakes produced using hard percussion were considered non-diagnostic.

Roughly half the lithic collection is made up of non-diagnostic pieces. The rest are mainly attributable to the Middle Palaeolithic $(\mathrm{N}=150)$ or "probable" Middle Palaeolithic $(\mathrm{N}=963)$. Only 16 lithic artefacts attributable to the Upper Palaeolithic or Epipalaeolithic were recovered (including: 4 blade cores, 1 core tablet, 4 microblade cores and a crescent microlith from a test pit at Gasparões). In addition, 11 Acheulean bifaces (or biface fragments) were identified from two localities (Vermelha, Cabeça do Marco). Finally, 6 metates, or grinding stones, and a polishing stone for shaping axe heads, associated with the Chalcolithic/Neolithic occupation of the region were recovered.

The dominant raw material (Fig. 3) by far is jasper ( $\mathrm{N}=1556$ pieces; almost $80 \%$ of the total). Quartz is the next most important raw material type $(\mathrm{N}=330 ; \sim 17 \%)$. Less than $2 \%$ of the artefacts are made of flint or chert, from only 19 locations - nearly one third of them north of Grândola. Less than $2 \%$ of the artefacts found are made of quartzite (from 17 locations). The re-

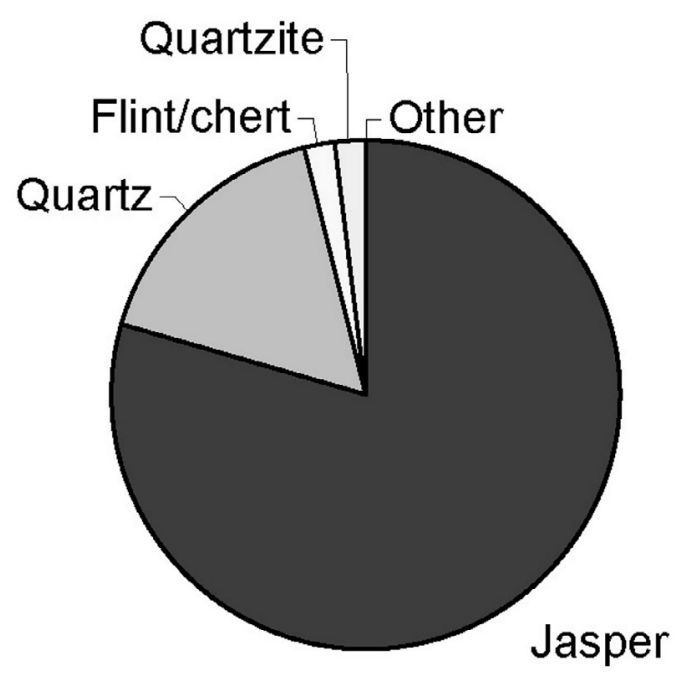

Fig. 3. Raw material distribution (\%). maining raw materials ("other") account for only $1 \%$ of the total collectively and include: rhyolites, sandstone (e.g., the metates) and unidentified rocks.

Quartz is locally available in primary veins and quartz cobbles are abundant on terraces and wherever the river system cross-cuts quaternary deposits in the south of the Sado Basin. Unfortunately, quartz is very diaclastic and does not fracture evenly; as a result it is less likely to present clear percussion landmarks. Since only flakes with diagnostic features were recorded, it is likely that quartz is under-represented in the archaeological assemblages. However, we believe that the dominance of jasper is not just an artefact of collection strategy, since it also has far better knapping qualities and was probably selectively used. Other raw materials suitable for knapping (e.g., fine-grained quartzite) are relatively rare in the study region and the relative proportion of these materials (Fig. 3) is probably representative of their overall availability. The percentage of jasper in a given assemblage is correlated with its proximity to primary deposits (outcrops), many of which were exploited, e.g., at Mina do Paço, Moínhos 1 and 2, and Cabeça do Marco, where assemblages are $>90 \%$ jasper (8). As a result, sites in the south of the target region (where most of the jasper outcrops exist) tend to be more heavily dominated by jasper.

Blade cores and blades are mostly found in terrace deposits (Alvalade, Chacafre, Mudança) and lakes (Sao Tiago, Gasparões, Lagoa de Pedra, Mingorra), highlighting the fact that these locations tend to contain chronologically mixed assemblages. A single blade fragment was found at Mina do Paços but it is very abraded relative to the rest of the material and was found on the periphery of the main artefact concentration - the integrity of the site and its attribution to the Middle Palaeolithic does not seem compromised, therefore. A naturally backed blade on jasper from Moínhos 1 is also very abraded, but it is possible that Moínhos 1 represents a chronologically mixed deposit (9). The metates come mainly from terraces in the planalto; two of the metates and the axe-head polishing stone are associated with

(8) Bisson, M.; Burke, A. and Meignen, L. (in press): Mina do Paço and Moinhos, Palaeolithic chipping stations in Southern Alentejo (Spain). O Arqueólogo Português.

(9) See note 8. 
the remains of a stone building foundation discovered along the river Chacafre; a metate was found north of Grândola, at Penique.

\subsubsection{Sites, localities and lithic scatters}

There are 83 locations with cultural remains in our database; 20 of these locations contain diagnostic lithic material (Fig. 4). All but one of the 20 locations with diagnostic lithics occur south of Grândola. 9 of these locations are identifiable as significant (sites/localities) using the criteria described above - all occur south of Grândola. Of the significant sites/localities, 2 are attributed to the Lower Palaeolithic (Acheulean) or early Middle Palaeolithic (Cabeça do Marco, Vermelha) and 6 are attributed to the Middle Palaeolithic (Brejo, Chacafre 2, Gasparões, Moínhos 1, Moínhos 2, and Paços). Pardieiro, a locality with a moderate number of artefacts $(\mathrm{N}=31)$, is potentially attributable to the Middle Palaeolithic but

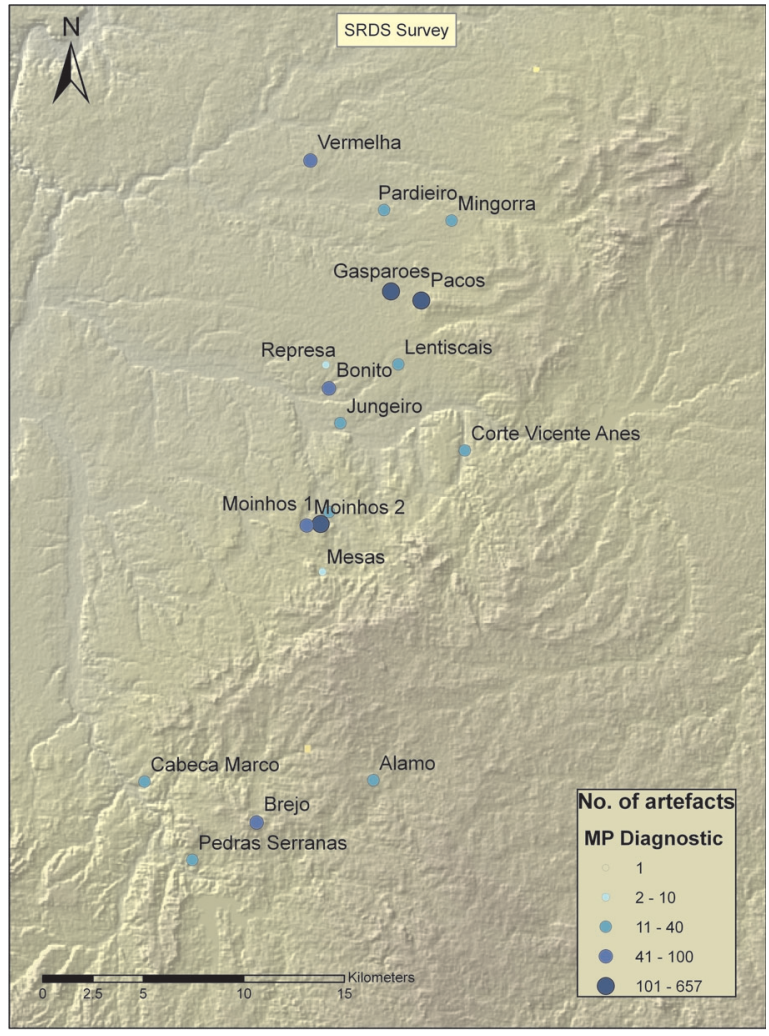

Fig. 4. SRDS survey. Sites and localities with diagnostic, Middle Palaeolithic artefacts. the assemblage is chronologically mixed and is not included in the site descriptions provided below. The remaining 11 locations are lithic scatters.

\section{Lower Palaeolithic sites and localities}

Cabeça do Marco: This locality is situated on the right bank of the Sado River at the confluence with the Ferraria River, on the upper terrace opposite a mapped jasper source. The assemblage numbers $\mathrm{N}=34$ lithics; most of the material was found mid-slope on the terrace, between about 100 and $110 \mathrm{~m}$ asl. A limited number of test cores were drilled into the talus with a vibra-corer but we were unable to establish whether or not in situ, archaeological levels exist under the surface of the terrace. The raw material used is predominantly jasper $(94 \%)$ and the presence of cortex on numerous pieces indicates that cobbles or rolled blocks were being exploited. The source of the raw material is therefore likely to be the Plio-Pleistocene terrace deposits available locally. The surface condition of the lithic assemblage points to a degree of heterogeneity; some pieces show signs of river transport, while others have remarkably "fresh" edges. This means that the assemblage itself likely represents a palimpsest, which is consistent with its location on a fluvial terrace. The presence of 3 bifaces in the assemblage allows us to attribute this locality to the Acheulean. Two of the bifaces are heavily rolled, the third (Fig. 5: 2) is relatively "fresh". All three bifaces have invasive flake removals. There are 13 cores in the assemblage and most are compatible with an Acheulean age attribution but the presence of discoidal cores, a centripetal core with preferential surface and a Levallois core, all with "fresh" edges, indicate the possibility of mixing with a later, Middle Palaeolithic occupation.

Vermelha: The locality is situated in a sandy, Miocene sedimentary context at $90 \mathrm{~m}$ asl, at the confluence of two small gullies, or barrancos, on the edge of a modern holding pond. The lithics were fairly concentrated $(\mathrm{N}=84)$. Raw materials are diversified though dominated by quartz $(42 \%)$ and jasper $(36 \%)$, quartzite $(10 \%)$ and other materials $(12 \%)$ including sandstone and greywacke. The presence of cortex on many pieces indicates use of cobbles, probably deriving from locally available Plio-Pleistocene deposits. 


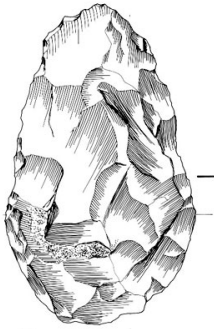

(A)
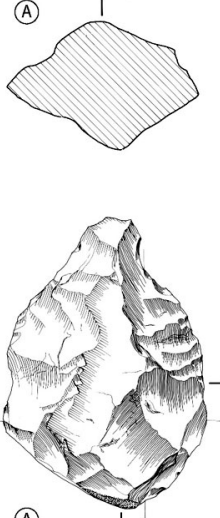

(A)

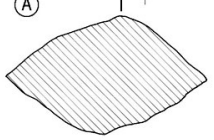

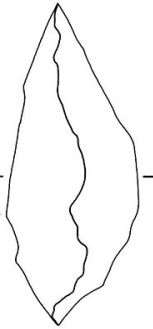

(B)

1
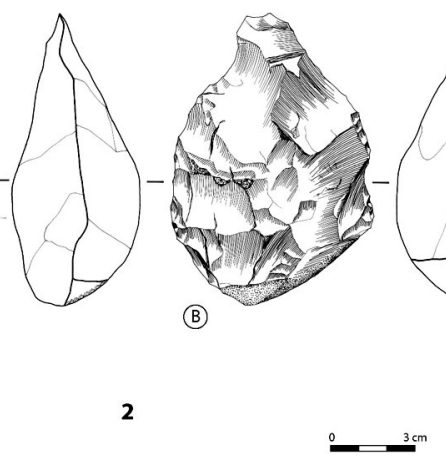

Fig. 5. Lithic artefacts from Cabeça do Marco and Vermelha.

Some of the jasper was obviously obtained from blocs with evidence of stream-rolling, but near a raw material source; the nearest known source for the jasper blocks is a river about 3-4 kms away that includes Mina do Paço in its hydrological ba$\sin$. The surface condition of the material is fairly fresh or weakly altered; post-depositional processes do not appear to have affected the assemblage to any great degree. The bifaces are thick and plano-convex in cross section (Fig. 6) or bi-convex (Fig. 5: 1) and are characterised by invasive retouch using hard hammer percussion; they are only slightly rolled or abraded. The raw materials include jasper or quartzite cobbles, greywacke, and an unidentified, black siliceous rock with white inclusions. Most of the remaining pieces are flakes; few of the quartz flakes show clear signs of anthropic modification, cortical and normal flakes are equally represented $(\mathrm{N}=21$ and 27, respectively) and there are no Levallois flakes. A single micro-blade core indicates some chronological mixing of the assemblage. The numerous cores $(\mathrm{N}=23)$ are all informal.

\section{Middle Palaeolithic sites and localities}

Brejo: This locality lies in the immediate vicinity of a jasper outcrop that forms a distinctive landscape feature. The medium-sized lithic concentration $(\mathrm{N}=63)$ was collected in proximity to the outcrop or on nearby slopes at about $210 \mathrm{~m}$ asl. There are few cortical pieces in this assemblage and it is likely that blocks detached from the outcrop were being exploited. Despite the dominance of jasper $(87 \%)$ there are also quartz $(8 \%)$ and other $(5 \%)$ raw materials in use (which likely derive from locally available Plio-Pleistocene cobble deposits). The surface condition of the lithics (relatively fresh or only slightly abraded) indicates that the material is largely in situ. The assemblage is mostly composed of normal flakes $(\mathrm{N}=40)$ with only 4 cortical flakes, 3 Levallois flakes, 4 tools and 12 cores of which 5 are atypical Levallois (4 centripetal, one unidirectional), 1 is discoidal and 1 is a summary, discoidal core (Fig. 7: 2-5). Globally, the assemblage appears homogeneous and can be attributed to the Middle Palaeolithic.

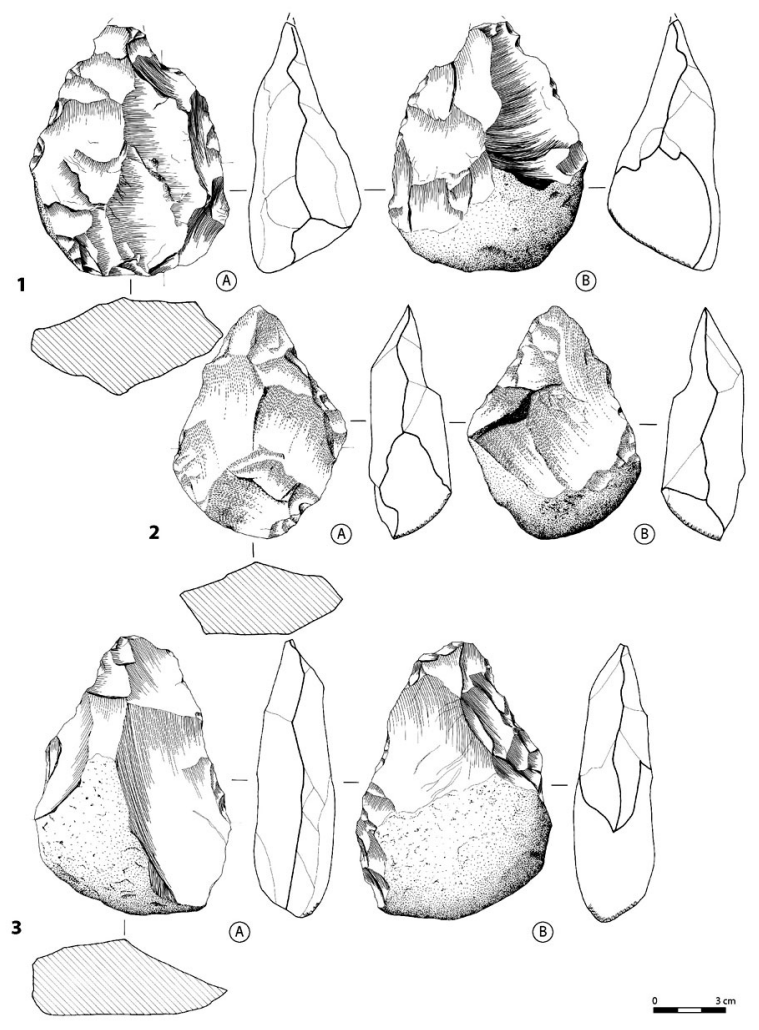

Fig. 6. Lithic artefacts from Vermelha. 


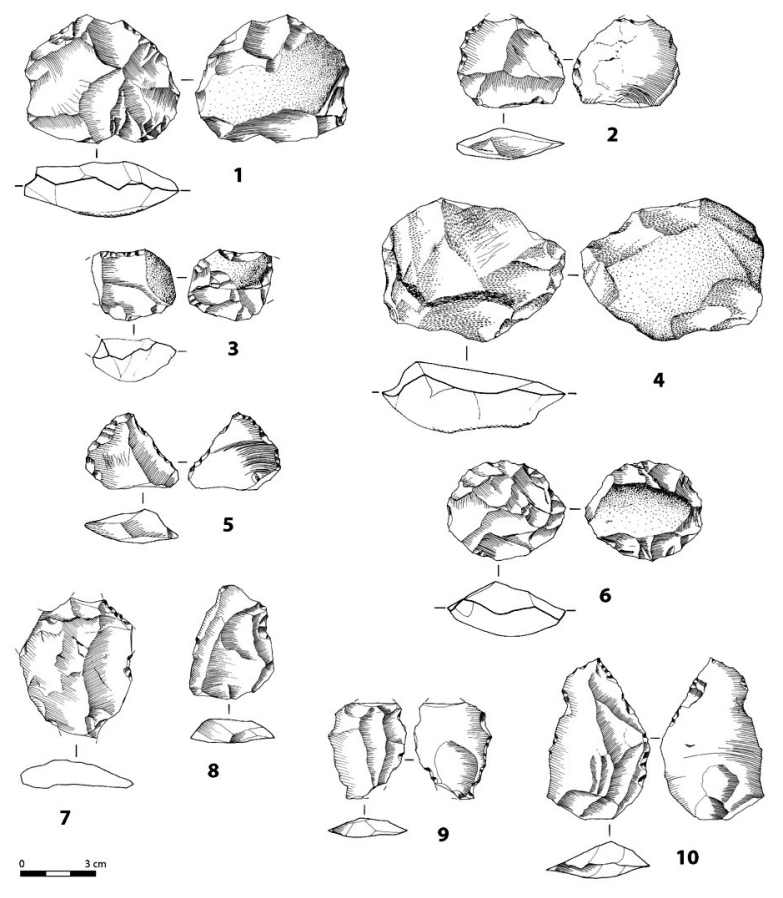

Fig. 7. Lithic artefacts from Brejo and Gasparões.

Chacafre 2: it is an open-air locality, situated on Plio-Pleistocene sediments on the banks of Barranco Chacafre (aka Xacafre) approximately $100 \mathrm{~m}$ asl. This medium-sized lithic concentration $(\mathrm{N}=80)$ is composed predominantly of jasper $(68 \%)$ and quartz $(31 \%)$ and a single piece of flint. Almost exclusive use of cobbles is indicated, in all likelihood derived from local Plio-Pleistocene sediments. The surface condition of the lithics is fairly fresh overall and the material is likely to be in situ. Cortical $(\mathrm{N}=25)$, normal $(\mathrm{N}=33)$ and Levallois $(\mathrm{N}=5)$ flakes, all obtained using hard percussion, are present as is one formal tool. 15 cores include one recurrent, centripetal Levallois core, 1 discoidal core and 4 partial discoidal cores, and 1 centripetal core with a preferential surface. On the whole, the assemblage appears Middle Palaeolithic in age (Fig. 7: 6-10). The presence of a microblade core on flint indicates some mixing with later occupation phases, however.

Gasparões: It is situated in a small, seasonal lake (or lagoa) in the village of the same name, at about $100 \mathrm{~m}$ asl. This locality contains a sizeable lithic series $(\mathrm{N}=145)$ and is located $1,5 \mathrm{~km}$ from Mina do Paço, an important jasper outcrop. The lithic series was mostly collected on the ploughed surface of the lake or immediately around its edges. In addition, three test pits were excavated to a depth of more than $1 \mathrm{~m}$ in 2007. Material was recovered within the plough zone in the test pits to a depth of about $40 \mathrm{~cm}$, indicating that the site (or sites) that once existed here is now disturbed. None of the material recovered from the test pits was diagnostic.

Jasper is the dominant raw material in this series $(82 \%)$ in keeping with its location in proximity to a major outcrop. Quartz (15\%), quartzite $(2 \%)$ and other raw materials $(1,5 \%)$ are also present. Most of the jasper was collected as cobbles or weathered blocks judging by the cortex; all of the other raw materials were collected as cobbles and are locally available. The surface condition of the lithics is generally good, indicating little movement. The assemblage is dominated by normal flakes $(\mathrm{N}=85)$ and cortical flakes $(\mathrm{N}=30)$ with one Levallois flake and three tools. Of the 14 cores, 2 are Levallois, recurrent centripetal cores (Fig. 7: 1), 2 are summary Levallois cores and 2 are discoidal. A small, concreted Levallois core with fresh edges, other (probable) Levallois cores and a scraper with scalar retouch (possibly Quina, although it could be the result of resharpening of a tool on a thick blank) suggest a Middle Palaeolithic occupation.

Pollen analysis at Gasparões: Dry sediment samples from Gasparões were prepared for pollen analysis following the standard protocol of the EPOC laboratory. The pollen counts for the uppermost 5 samples are shown in table 1. The overall composition for the uppermost 2 samples for which relatively large counts could be obtained is summarised in figure 8 . The samples are dominated by Isoetes spores, accompanied by other taxa indicative of seasonal inundation (Ophioglossum lusitanicum) and/or humid conditions (Apiaceae, Cyperaceae, Ranunculus) which are probably derived from local vegetation growing within the lake basin. The remaining pollen reflects vegetation in surrounding dry ground habitats, with a mixture of tree, shrub and herbaceous taxa suggesting an open landscape with some trees. Pollen of Pinus, Olea (olive) and Cereal type in the uppermost sample probably reflect agro forestry and agricultural activities in the surrounding region. Between the core-top and $0.77 \mathrm{~m}$, the samples become progressively poorer in pollen material, and the lowermost 7 samples are completely sterile (no pollen grains or spores encountered on the slides). The reduction 


\begin{tabular}{|c|c|c|c|c|c|c|c|c|c|c|c|c|}
\hline Upper depth (m) & $\mathbf{0}$ & 0,25 & 0,35 & 0,52 & 0,72 & 0,92 & 1,12 & 1,32 & 1,42 & 1,7 & 1,9 & 2,02 \\
\hline Depth range (m) & $\begin{array}{c}0.00- \\
0.10 \mathrm{~m}\end{array}$ & $\begin{array}{c}0.25- \\
0.30 \mathrm{~m}\end{array}$ & $\begin{array}{c}0.35- \\
0.40 \mathrm{~m}\end{array}$ & $\begin{array}{c}0.52- \\
0.57 \mathrm{~m}\end{array}$ & $\begin{array}{c}0.72- \\
0.77 \mathrm{~m}\end{array}$ & $\begin{array}{c}0.92- \\
0.97 \mathrm{~m}\end{array}$ & $\begin{array}{c}1.12- \\
1.17 \mathrm{~m}\end{array}$ & $\begin{array}{c}1.32- \\
137 \mathrm{~m}\end{array}$ & $\begin{array}{c}1.42- \\
1.47 \mathrm{~m}\end{array}$ & $\begin{array}{c}1.70- \\
1.75 \mathrm{~m}\end{array}$ & $\begin{array}{c}1.90- \\
1.96 \mathrm{~m}\end{array}$ & $\begin{array}{c}2.02- \\
2.04 \mathrm{~m}\end{array}$ \\
\hline $\begin{array}{l}\text { Exotic (Lycopodium) } \\
\text { counted } \\
\text { Pinus } \\
\text { Quercus deciduous type } \\
\text { Quercus evergreen type } \\
\text { Olea } \\
\text { Ericaceae } \\
\text { Calluna } \\
\text { Helianthemum } \\
\text { Aster type } \\
\text { Asteraceae (fenestrate) } \\
\text { Caryophyllaceae } \\
\text { Cereal type } \\
\text { Chenopodiaceae } \\
\text { Plantago } \\
\text { Plumbaginaceae } \\
\text { Poaceae } \\
\text { Rumex } \\
\text { Apiaceae } \\
\text { Cyperaceae } \\
\text { Ranunculus } \\
\text { Myriophyllum alterniflorum } \\
\text { Isoetes } \\
\text { Monolete spores } \\
\text { Anthoceros } \\
\text { Ophioglossum lusitanicum } \\
\text { Trilete spores } \\
\text { Pseudoschitaea circula } \\
\text { Broken } \\
\text { Corroded } \\
\text { Crumpled } \\
\text { Unknown } \\
\text { Total Indeterminate }\end{array}$ & $\begin{array}{r}72 \\
50 \\
9 \\
5 \\
12 \\
3 \\
1 \\
5 \\
3 \\
1 \\
1 \\
2 \\
1 \\
1 \\
29 \\
2 \\
3 \\
1 \\
1 \\
297 \\
\\
1 \\
2 \\
3 \\
4 \\
\\
1 \\
1 \\
2\end{array}$ & $\begin{array}{r}2 \\
1 \\
1 \\
154 \\
1 \\
\\
2 \\
1 \\
3 \\
6 \\
1 \\
1 \\
8\end{array}$ & $\begin{array}{r}985 \\
2 \\
2 \\
3\end{array}$ & 1 & 440 & 237 & 261 & $>100$ & $>100$ & $>100$ & $>100$ & $>100$ \\
\hline $\begin{array}{l}\text { Trees } \\
\text { Shrubs } \\
\text { Dry ground } \\
\text { Humid ground } \\
\text { Spores (ferns and allies) } \\
\text { Total palynomorphs }\end{array}$ & $\begin{array}{r}76 \\
4 \\
45 \\
5 \\
303 \\
441\end{array}$ & $\begin{array}{r}32 \\
9 \\
34 \\
4 \\
158 \\
256\end{array}$ & $\begin{array}{r}7 \\
3 \\
7 \\
2 \\
57 \\
82\end{array}$ & $\begin{array}{r}1 \\
1 \\
1 \\
1 \\
12 \\
18\end{array}$ & $\begin{array}{r}0 \\
0 \\
1 \\
0 \\
23 \\
24\end{array}$ & $\begin{array}{l}0 \\
0 \\
0 \\
0 \\
0 \\
0\end{array}$ & $\begin{array}{l}0 \\
0 \\
0 \\
0 \\
0 \\
0\end{array}$ & $\begin{array}{l}0 \\
0 \\
0 \\
0 \\
0 \\
0\end{array}$ & $\begin{array}{l}0 \\
0 \\
0 \\
0 \\
0 \\
0\end{array}$ & $\begin{array}{l}0 \\
0 \\
0 \\
0 \\
0 \\
0\end{array}$ & $\begin{array}{l}0 \\
0 \\
0 \\
0 \\
0 \\
0\end{array}$ & $\begin{array}{l}0 \\
0 \\
0 \\
0 \\
0 \\
0\end{array}$ \\
\hline $\begin{array}{l}\text { Exotic counted } \\
\text { Exotic added } \\
\text { Concentration } \\
\text { (palynomorphs/s) }\end{array}$ & $\begin{array}{r}72 \\
37166 \\
227642\end{array}$ & $\begin{array}{r}440 \\
37166 \\
21624\end{array}$ & $\begin{array}{r}985 \\
37166\end{array}$ & $\begin{array}{r}492 \\
37166 \\
\\
1360\end{array}$ & $\begin{array}{r}440 \\
37166 \\
\\
2027\end{array}$ & $\begin{array}{r}237 \\
37166\end{array}$ & $\begin{array}{r}261 \\
37166\end{array}$ & $\begin{array}{r}31 \\
37166\end{array}$ & $\begin{array}{r}31 \\
37166\end{array}$ & $\begin{array}{r}31 \\
37166\end{array}$ & $\begin{array}{r}31 \\
37166\end{array}$ & $\begin{array}{r}31 \\
37166\end{array}$ \\
\hline
\end{tabular}

Tab. 1. Pollen spectrum from Gasparões (Alentejo).

in pollen and spore concentrations by a factor of 10 over the uppermost $30 \mathrm{~cm}$, and by a factor of 100 over the uppermost $50 \mathrm{~cm}$ indicates a severe, progressive down-sequence loss of palynological material. Given the highly minerogenic and apparently non-waterlogged nature of the sediments coupled with the Mediterranean-type climate of the region, this loss is most likely related to physical and chemical decay associated with seasonal wetting-drying cycles and oxidising conditions, possibly accompanied by biological attack by microbial activity. Unfortunately, the lack of preserved palynological material in all but the uppermost $30 \mathrm{~cm}$ of the Gasparões sequence suggests that this site is not suitable for palaeoecological investigation using palynology.

Mina do Paço: This site is located at a jasper outcrop and is the largest concentration of 


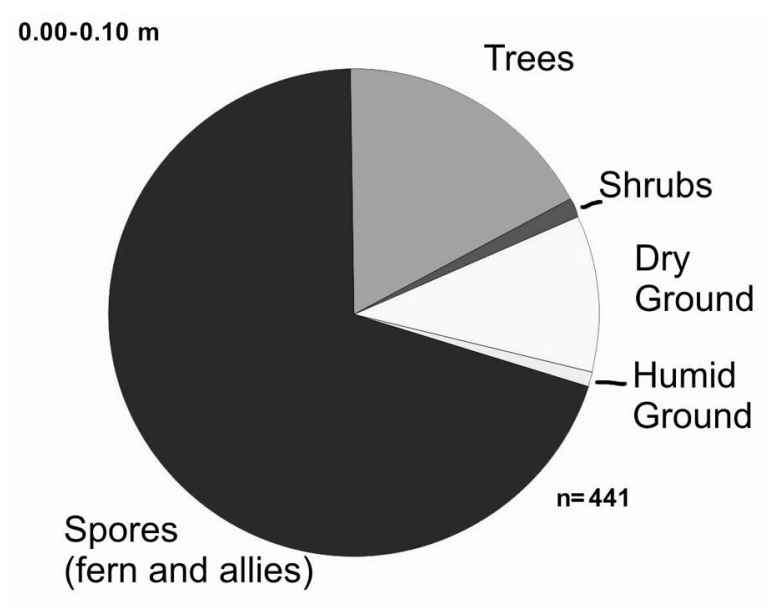

$0.25-0.30 \mathrm{~m}$

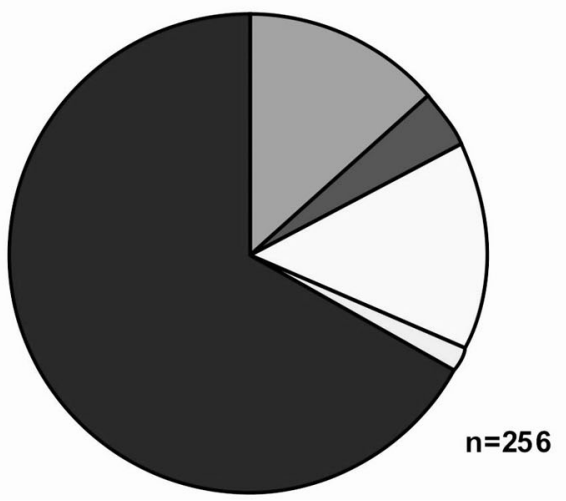

Fig. 8. Summary of pollen components for 2 uppermost samples from Gasparões.

Palaeolithic materials discovered by the SRDS survey $(\mathrm{N}=707)$. It is situated on the southwest end of a ridge, c. $1.5 \mathrm{~km}$ northeast of Gasparões (above). The site is well-defined spatially despite being located in the midst of an abandoned $20^{\text {th }}$ Century mine, recently transformed into a very large olive plantation. Because the surface disturbance is recent and the lithics are distributed in a clearly defined area, Mina do Paço can be considered essentially in situ. Most of the artefacts are only very slightly abraded, suggesting relatively little down slope movement since their discard, although damaged edges suggest trampling. Ploughing afforded excellent soil visibility, and surface collections were conducted on this site in 2006, 2007 and 2008. Excavation of four $1 \times 1 \mathrm{~m}$ test pits established that the artefacts are restricted to the plough zone. The jasper vein exposed by the modern mine is vertical in orientation, 30-40 cm thick, and cuts through green-gray schist country-rock. Because modern mining (involving at least 4 shafts) has significantly altered the terrain immediately around the jasper deposit, a significant proportion of the site has been destroyed and it is impossible to determine how much of the outcrop was exposed during the Palaeolithic. The weathered jasper blocks that occur on the hillside were probably the main source of lithic raw material for prehistoric knappers. The surface collections and test pits at Mina do Paço yielded $N=707$ lithic specimens of which 657 were collected and catalogued - of these, 449 are large enough ( $\geq 1.5 \mathrm{~cm}$ maximum dimension) for analysis. The assemblage (Fig. 9) includes 63 cores, 375 flakes and fragments, 9 retouched flake tools and two hammerstones. The artefacts are almost exclusively jasper $(99.3 \%)$, and 2 of the 3 non-jasper specimens are hammerstones. The cores are dominated by preferential $(23.8 \%)$ and recurrent Levallois types (22.2\%) indicative of a Middle Palaeolithic occupation. There are an additional 7 cores with preferential faces but cortical striking platforms; although they do not correspond to the strict definition of Levallois used here (Boëda 1994), these cores bring the total of Levallois or Levallois-like cores to $57.1 \%$. Informal cores $(19 \%)$ and cores on flakes $(11.1 \%)$ outnumber discoidal cores $(7.9 \%)$, the most common category at Moínhos 1 and 2 (see below). Pyramidal (3.2\% and bipolar (1.6\%) cores are rare. Face preparation is predominantly cen-

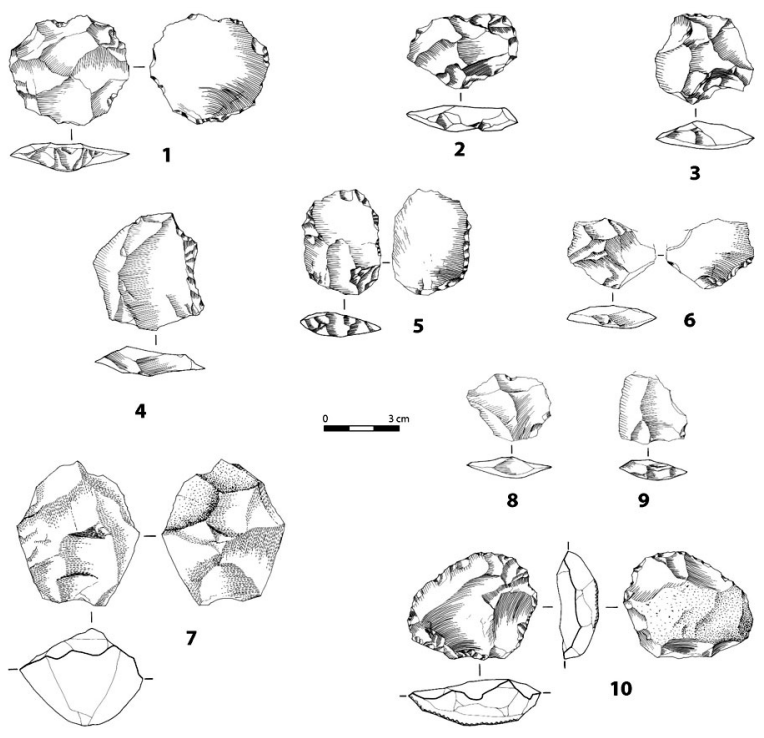

Fig. 9. Lithic artefacts from Mina do Paço. 
tripetal $(56.6 \%)$, but unidirectional, irregular preparation is also common $(39.6 \%)$. There were 188 whole flakes and 187 flake fragments. Among the whole flakes, cortex is common $(44.1 \%)$ as would be expected on a site where primary knapping is taking place. Levallois flakes are common $(15.4 \%)$. Most flakes have either cortical or plain striking platforms $(65.4 \%)$; faceted platforms $(26.5 \%)$ outnumber dihedral platforms $(8.2 \%)$. A single rolled blade found on the periphery of the main artefact concentration may not be Middle Palaeolithic. The 9 formal tools from Mina do Paço are simple and minimally retouched. Notched forms predominate, with two single notches, two double notches and one denticulate. Notches and denticulates are often found in greater numbers in open-air and at lithic sources, however (Mellars 1996), and are very common in the MP of Portugal and the rest of Iberia (Angelucci and Zilhão 2009; Raposo and Cardoso 1998; Raposo and Santonja 1995). The assemblage includes three examples of Bordes (Bordes 1961) tools of "Upper Palaeolithic type" on typical Middle Palaeolithic flake blanks: an endscraper on a Levallois flake, a burin on the interior face and a small perçoir. A retouched flake fragment may be part of an endscraper on a Levallois flake; there are no lateral scrapers in this collection. Mina do Paço may have been primarily a lithic acquisition site, but the presence of unretouched Levallois flakes, which could have served as expedient cutting tools on soft materials such as meat and hide (Debénath and Dibble 1994), and of notched forms indicative of the occasional renewal of tools made of organic materials, suggest that the site also served as a temporary camp. Its location may have allowed hunters to spot game approaching the Gasparões lake.

Moínhos 1: This site contains a relatively large lithic assemblage $(\mathrm{N}=129)$ recovered in the immediate vicinity of an important raw material source (a jasper outcrop) on the slopes below the outcrop and in the bed of a small swayle, the Barranco de Milhouros. Material was selectively collected from this location due to the presence of a historic mineshaft and abundant evidence of machine shattered jasper flakes. Big blocks of jasper (10-40 cm in diameter) litter the slopes below the outcrop and the outcrop itself is heavily fractured and diaclastic. The assemblage is dominated by jasper $(94.6 \%)$ of the total assemblage) and many of the pieces have worn, cortical surfaces (corresponding to diaclastic fracture planes), indicating that weathered blocks, rather than the primary outcrop itself, were being exploited. The assemblage from Moínhos 1 is almost entirely abraded or rolled, and there are frequent signs of abrupt, alternate retouch,consistent with its position on a slope. Pieces at the base of the slope and in the swayle below the site are the most heavily altered. The homogeneity of the assemblage is therefore not proven. The percentage of cortical flakes is relatively high $(20.2 \%)$ and the percentage of cores $(41.9 \%)$ is also very high, indicating that primary debitage was taking place on site. Only two retouched tools (a scraper on the interior surface and a scraper with proximal thinning) are present, and two Levallois flakes. Most of the pieces (including 8 Levallois cores and 4 cores with preferential faces) are either attributable to the Middle Palaeolithic, or do not contradict a hypothetical Mousterian occupation. 10 bifacial pieces (Fig. 10) of uncertain chronological attribution complicate the interpretation of the site,

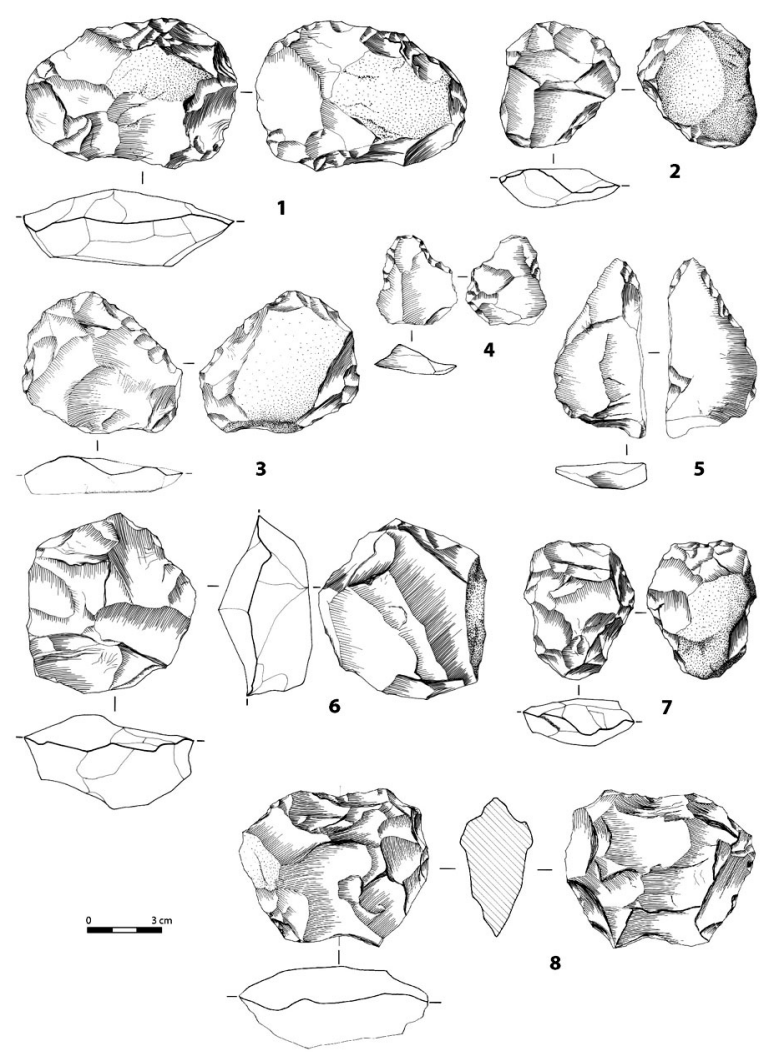

Fig. 10. Lithic artefacts from Moínhos. 
however. These specimens, which range from pointed to roughly circular in plan form, are crudely executed and do not match the pointed forms and cleavers that are common in the Portuguese Acheulean (Mozzi et al. 2000; Raposo et al. 1993; Viana 1945) or the bifacial preforms of the Portuguese Chalcolithic (Forenbaher 1998). Because they tend to have plano-convex crosssections with larger flake removals on the flatter of the two faces and because there is no evidence of attempts to regularize their edges, they are classified here as biface-cores (10). Although these bifacial pieces are not diagnostic of an Acheulean occupation, the poor quality of the jasper from this location may have created atypical products. It is possible, therefore, that this jasper vein was exploited at different times during prehistory. Informal cores are the most common core form at Moínhos 1, characterized by a single platform and a small number of flake removals (31.3\% of all cores); partial and complete discoid cores $(28.1 \%)$; Levallois cores and cores with preferential faces (aggregate 18,8\%), biface-cores $(15.6 \%)$ and other forms, including 3 Levallois-like cores on large flakes, constituting the remaining $6.2 \%$. The dominance of informal cores is to be expected in a situation where weathered blocks of diaclastic jasper were being tested. Centripetal preparation is present on $66.1 \%$ of cores, with almost all of the remainder having unidirectional irregular preparation. Platform faceting is present on only $28.2 \%$ of cores. Cortical platforms predominate $(49.1 \%)$ and only $13.2 \%$ of the flakes have dihedral or multi-faceted platforms. The large number of cores and the scarcity of end products such as formal tools and Levallois flakes suggest that lithic acquisition and knapping were the primary activities carried out at this site (11).

Moínhos 2: This locality is a medium-sized $(\mathrm{N}=71)$ lithic concentration from a relatively circumscribed surface scatter on a west-facing slope, a few hundred meters from Moínhos 1 . There is a buried intrusion of jasper at this site, and weathered blocks occur on the surface; the assemblage is dominated by jasper $(93 \%)$ but also contains a few quartzite and quartz pieces. A number of pieces $(37.3 \%)$ have abraded cortex consistent with natural diaclastic fracture planes,

(10) See note 8 .

(11) See note 8. indicating exploitation of exposed blocks. Some pieces also indicate the use of cobbles (e.g., the quartz and quartzite pieces) which would have been collected from local Plio-Pleistocene deposits. Although $62 \%$ of the specimens are abraded this collection exhibits less overall postdepositional damage than does Moínhos 1 . The level of abrasion indicates gentle down slope movement or water action, with only seven pieces presenting evidence of heavy rolling. Most of the assemblage is therefore essentially in situ. Ordinary and cortical flakes dominate $(29.6 \%$ and $26.7 \%$ respectively) and cores are frequent $(28.2 \%)$. Discoids are the most common type (35\% of cores); followed by informal (30\%); Levallois $(15 \%)$, preferential centripetal $(10 \%)$ and two-platform $(10 \%)$. A single retouched tool, a scraper with proximal thinning, was recovered and there are no Levallois flakes. The frequencies of technological attributes at Moínhos 1 and 2 are similar and centripetal core exploitation strategies are essentially identical (12). The locality is attributable to the Middle Palaeolithic on the basis of the Levallois, discoidal and preferential centripetal cores. The abundance of cores and debris and the scarcity of products and formal tools indicate that, like Moínhos 1, Moinhos 2 was used predominantly as a lithic provisioning site.

Moínhos 1, Moínhos 2 and Mina do Paço are the three most prominent lithic acquisition and processing stations identified by the SRDS. Because they are relatively rich in technological elements, they are particularly informative of the relationship of the Palaeolithic of the Sado basin to other regions in Iberia. Differences in core type frequencies between Moínhos 1 and 2 (more discoidal) and Mina do Paço (more Levallois) are probably attributable to the quality of jasper at each locality. The jasper at Mina do Paço is less diaclastic than at Moínhos 1 and 2, where a more expedient discoidal strategy may have been preferable. These three locations are dominated by centripetal Levallois and discoidal debitage, which is a common pattern for Middle Palaeolithic assemblages in Portugal (Raposo 1995; Zilhão 2006). Discoidal cores also occur in Late Aurignacian assemblages elsewhere in Portugal in association with blade cores (Aubry et al. 2006) - which do not occur in the Sado River Ba- 
sin sample. Typological comparisons of these sites to dated Middle Palaeolithic assemblages in Iberia are possible, but some caution is necessary because discoid and Levallois cores can grade into each other (Raposo 2000) if applied to poorer quality raw material like quartz, quartzite and jasper. Notwithstanding this concern, these three assemblages most closely resemble those dated to the late Middle Palaeolithic in southern Iberia (Zilhão 2006), where centripetal discoidal and Levallois cores are common. The limited number of retouched tools in the Sado Basin sites is also consistent with other Portuguese assemblages dated to the late MP (13). Nevertheless, firm dating of the Sado Basin MP awaits the discovery of datable in situ material.

\section{Other localities and lithic scatters}

Of the remaining 11 survey locations containing diagnostic material (but with low kernel density values) Alamo and Pedras Seranas are small lithic scatters of probable Middle Palaeolithic age located on raw material outcrops, Rio Moínhos and Bonito are lithic scatters containing mostly Middle Palaeolithic material (with some mixing) located on riverbanks cutting into Plio-Pleistocene or Miocene sediments, and Jungeiro, Lentiscais, and Mingorra are lithic scatters of probable Middle Palaeolithic age associated with a series of small, ephemeral lakes occurring on the planalto (Fig. 4). The remainder of locations containing diagnostic, Middle Palaeolithic lithics (Corte Vicente Anes, Mesas, Represa) are lithic scatters with mixed assemblages or are too small to attribute to a particular chronological period.

In addition to the above, 7 sizeable lithic scatters (containing roughly 20-50 artefacts) lacking diagnostic material were identified (Arca, Arouca, Chacafre, Faias, Lagoa da Pedra, Mudança and São Tiago). Three of these lithic scatters are in the northern half of the study region (Arca, Arouca, Faias) and the remainder are river terraces (Chacafre, Mudança) or lakes (Lagoa da pedra, São Tiago) in the south. The remaining survey locations are small lithic scatters $(\mathrm{N}=2-20)$ or isolated finds of indeterminate age, mostly comprised of flakes. 2 potential Chalcolithic/ Neolithic sites (including one with architectural remains) were discovered during

(13) See note 8 . survey in the planalto and brought to the attention of local authorities; these sites were not fully surveyed are not reported upon here.

Test pits were excavated at Gasparões and at the nearby site of Mina do Paço in 2006, and at Moínhos 1 and Vermelha in 2007. The tests confirmed that archaeological materials recovered during the SRDS survey lie within the plough-zone (i.e., the top $30 \mathrm{~cm}$ of soil, disturbed by ploughing). Additional coring performed at Cabeça do Marco, Rio Moínhos and Mudança in 2008 did not yield evidence of artefacts below the surface. These results are consistent with a lack of surface aggradations in relation to colluvial or pedogenetic processes and could indicate that these localities are all that remain of archaeological sites obliterated by historical agricultural activity.

\section{DISCUSSION}

Generally speaking, terraces and ancient land surfaces in the northern portion of the survey region (north of Grândola) yielded only a handful of localities/lithic scatters. None of these are significant in terms of this analysis, with the possible exception of Penique - a jasper outcrop. In many cases, it seems that the terraces (or land surfaces) have been reworked by aeolian processes rendering them indistinguishable from later, Holocene deposits (see sedimentary history, above). As a result, much of the archaeological material recovered is likely to have been redeposited. This suspicion is confirmed by the chronologically mixed and frequently abraded nature of the lithic collections from the northern half of the study region. The southern part of the target region (south of Grândola) yielded more satisfactory results - all of the sites/localities and most of the unmixed lithic scatters containing diagnostic material come from this sub-region. Spatial patterning will only be analysed for the southern part of the target region (below).

\subsection{Spatial patterning}

Geographical variables are known to affect how humans settle a landscape; for example, the location of archaeological sites can be a function of distance to the nearest water source, slope and 
elevation. For this analysis, we used arcGIS to create a weighted cost surface using slope values (derived from the SRTM DEM) to assess the impact of distance to water and distance to raw material sources on site placement. The software's algorithm uses friction layers and destination features to calculate a weighted cost-surface. A slope map can be used as a simple indicator of terrain roughness, and was therefore directly implemented as the friction surface. This means that slope gets a weighting of $100 \%$ when factored as a coefficient for the friction surface. The destinations can be points, lines, polygons, or other clusters of cells. The analysis tool in ArcGIS assigns values into a new coverage map, which indicates the relative cost of moving away from source locations and across the cost surface. The resulting values on the weighted cost-surface map are cumulative, and are always computed relative to the destination that is the least costly to reach. The cost values themselves can be interpreted as time, expendable energy, or even a unitless cost value, depending entirely on the values of the initial

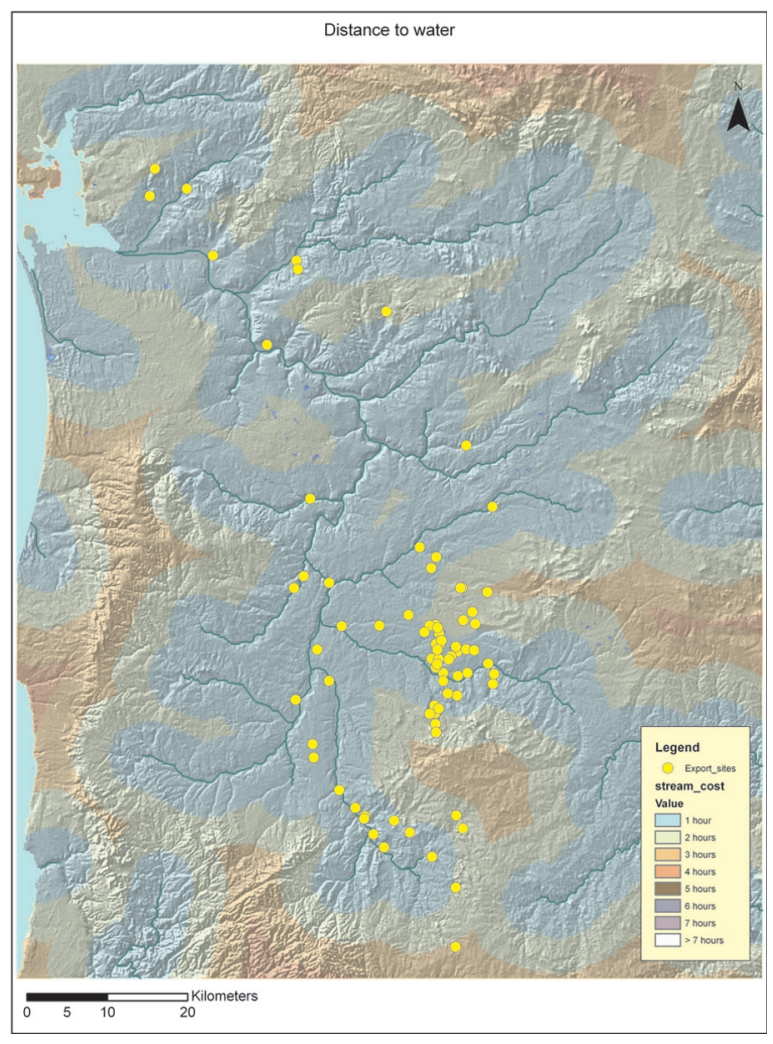

Fig. 11. SRDS survey. Distance to water, using a cost surface. friction surface. We used the existing hydrology, selecting primary rivers to represent permanent water sources for this analysis as they are more likely to reflect the paleolandscape than smaller tributaries and lagoas (Fig. 11). Known raw material sources were identified from maps provided by Dr. Matos (INETI). Figure 12 shows weighted distances from known jasper sources within the study region (showing only sites, localities and lithic scatters).

A majority of the sites and localities discovered during the survey lie within a one-hour walk from a permanent water source; given that the study region is generally well-irrigated this is hardly surprising, however, and distance to water is not considered a key limiting factor in our analysis. The two largest sites (Mina do Paço, Moínhos 1) lie further from permanent water; these locations, as well as Moinhos 2, could be governed by another variable - the distribution of raw material sources. Mina do Paço is also less than an hour's walk from the seasonal lagoa associated with the locality of Gasparões, which our analysis

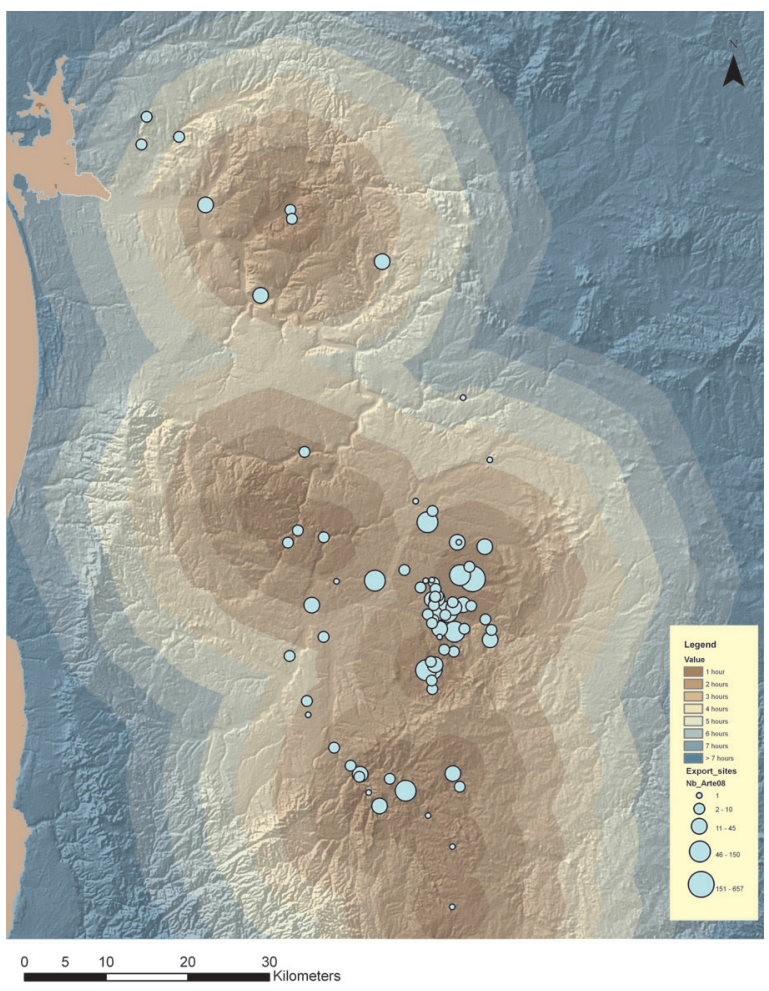

Fig. 12. SRDS survey. Distance to jasper sources, using a cost surface. 
indicates probably existed during the late Pleistocene (below).

The largest sites (100+ artefacts) are within 5 $\mathrm{km}$ of a jasper source (Mina do Paço, Moínhos 1, Gasparões) as are just over $50 \%$ of the remaining localities and lithic scatters. The vast majority of localities and lithic scatters lie within $10 \mathrm{~km}$ of a jasper source with all of the localities falling within this category. The largest concentration of sites, localities and lithic scatters occurs between Moínhos and Paços, where the $10 \mathrm{~km}$ provisioning zones of the two jasper sources overlap. Furthermore, a cost surface analysis reveals that the intervening space between the two mines presented no barriers to easy travel. Another, smaller grouping of sites occurs in the vicinity of Panóias and Brejo where multiple, small jasper outcrops are mapped.

The distribution of archaeological material, therefore, appears linked to the distribution of jasper outcrops. Although the lithic analysis (above) indicates that people were exploiting weathered blocks as well as jasper cobbles in secondary position, these are more likely to occur downstream and in proximity to the primary sources.

We could expect jasper outcrops associated with visually prominent topographic features to be more intensively exploited since they would have been more easily consigned to memory and their location described to others. To test this proposition, we first produced a total viewshed analysis of the study region in arcGIS (Fig. 13). A total viewshed assesses the visibility of each cell from all of the other cells within a defined

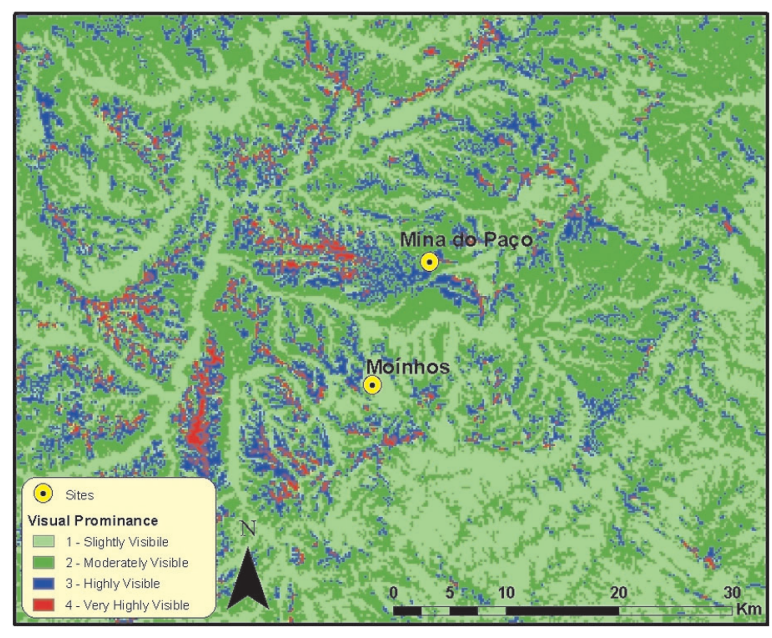

Fig. 13. Moinhos and Mina do Paço: visual prominence. viewing radius. For this analysis we used a cellsize of $180 \mathrm{~m}$ (twice the size of the original DEM cells) and a viewing radius of $20 \mathrm{~km}$. We then tested the possibility of there being a correlation between the visual prominence of an outcrop $(\mathrm{N}=16)$ and the total number of artefacts associated with it using a 1-tailed Pearson's coefficient. There is a significant, positive correlation between these two variables $(r=0.493, p=0.05$, $\sigma=0.26$ ) indicating that visual prominence played a role in determining how often a raw material source was used.

Viewshed analyses were also carried out for several of the jasper sources (Moínhos, Mina do Paço, Brejo, Penique) -this time, the visible cells in the surrounding region that can be seen from the source (the source's viewshed) were calculated. It is interesting to note that two sources are inter-visible: Moínhos and Mina do Paço. Furthermore, the largest viewshed, i.e., the one offering the best view of the study region, occurs at Mina do Paço - a site from which several other localities (including Moínhos) are visible.

A pattern of land use in the southern part of the Sado River Basin emerges from the data presented above. Several of the known primary jasper sources, most of which are concentrated in the southern part of the Basin, were exploited during the Middle Palaeolithic. The relative visibility of the jasper outcrops conditioned how often they were exploited. The two most significant Middle Palaeolithic sites encountered during this survey are located on jasper outcrops (Mina do Paço and Moínhos 1). The size of the assemblages at both sites indicates their probable use over relatively long periods of time. The locality of Moínhos 2 (near Moínhos 1) also yielded a significant Middle Palaeolithic assemblage and is in an area with abundant blocks of jasper on the surface (14). Other known, primary jasper sources exploited during the Middle Palaeolithic include Brejo, Alamo, and Pedras Seranas. The ratio of cores to flakes at these sites indicates sporadic and short-term use (although Brejo is a larger assemblage and was either visited for longer or more frequently). There are no visible sign of raw material extraction and weathered blocks detached from the outcrops are probably what attracted people to these locations.

(14) See note 8 . 


\begin{tabular}{|c|c|c|c|c|c|c|c|c|c|}
\hline Sample & $\begin{array}{c}\text { Depth of } \\
\text { sample } \\
(\mathbf{c m} \text { below } \\
\text { surface) }\end{array}$ & $\begin{array}{c}\text { ED } \\
\text { Value } \\
(\mathbf{G y}) \\
{[\mathbf{b}]}\end{array}$ & $\begin{array}{c}\text { Analytical } \\
\text { Error }(\mathbf{G y}) \\
{[\mathbf{b}]}\end{array}$ & $\mathbf{T h}(\mathbf{p p m})[\mathbf{c}]$ & $\mathbf{K}(\mathbf{p p m})[\mathbf{c}]$ & $\begin{array}{c}\text { Water } \\
\mathbf{c o n t e n t} \\
\mathbf{( \% )}[\mathbf{d}]\end{array}$ & $\begin{array}{c}\text { Cosmic } \\
\text { Dose Rate } \\
(\mu \mathbf{G y} / \mathbf{a}) \\
{[\mathbf{e}]}\end{array}$ & $\begin{array}{c}\text { Annual Dose } \\
(\mu \mathbf{G y} / \mathbf{a})\end{array}$ & $\begin{array}{c}\text { SAR-OSL age } \\
(\mathbf{y r s})\end{array}$ \\
\hline GASP S3S OSL1 & 135 & {$[\mathrm{a}]$} & $0.53 \pm 0.1$ & $3.57 \pm 0.23$ & $3073 \pm 88$ & 6 & $\mathrm{n} / \mathrm{a}$ & $\mathrm{n} / \mathrm{a}$ & $\mathrm{n} / \mathrm{a}$ \\
GASP S3S OSL2 & 35 & 7,04 & $0.77 \pm 0.1$ & $3.14 \pm 0.19$ & $4111 \pm 113$ & 3 & 240 & $1044 \pm 21$ & $6700+/-1,500$ \\
GASP S3S OSL3 & 25 & 1,73 & $0.87 \pm 0.1$ & $3.93 \pm 0.26$ & $4862 \pm 128$ & 3 & 251 & $1205 \pm 24$ & $1400+/-1,500$ \\
GASP S3S OSL4 & 15 & 1,48 & $0.92 \pm 0.1$ & $3.79 \pm 0.23$ & $4469 \pm 122$ & 4 & 263 & $1173 \pm 22$ & $1300+/-420$ \\
\hline
\end{tabular}

Tab. 2. OSL dates from Gasparões (GASP).

SAR-OSL ages and data for sand samples taken from Pit S3S-SRDS, Gasparões (Alentejo, Portugal). Ages were calculated assuming constant.

sediment accumulation rates (i.e. linear sediment accumulation) and rounded up. All $\beta$ and $\gamma$ dose rates were calculated based on $\mathrm{U}$, Th and $\mathrm{K}$.

concentrations of each sample accounting for moisture values of the sample.

[a] After initial measurements, this sample was too old to be dated by OSL (initial does obtained > $100 \mathrm{~Gy}$ ).

[b] Equivalent doses and errors from aliquots measured with $3 \mathrm{~mm}$ mask.

[c] U, Th and K values determined by NAA at Nuclear Reactor facility, McMaster University.

[d] Water content as a fraction of dry weight determined from laboratory measurements.

[e] Cosmic dose rate value calculated using an overburden density of $2 \mathrm{~g} / \mathrm{cm}^{2}$.

Another possible attractor on the landscape is the series of small, ephemeral lakes (lagoas) that occur in interfluvial contexts on the planalto, predominantly in Plio-Pleistocene contexts. Hominid occupations in the vicinity of the lakes during the Middle Palaeolithic are suggested by sites such as Gasparões. Gasparões lies within sight of Mina do Paço and may well be contemporaneous; we cannot substantiate this, however, since testing carried out in 2007 showed that artefactual material at Mina do Paço and Gasparões lies within the plough-zone and cannot, therefore, be securely dated; there has also obviously been some mixing of material at Gasparões. Several other lagoas contain Palaeolithic material (including: Jungeiro, Lentiscais, Mingorra, São Tiago and Lagoa da Pedra) indicating that these small depressions, located on interfluves, may have attracted hominids (and their prey) on a fairly regular basis, perhaps seasonally. This could indicate the importance of lacustrine settings in Alentejo during the Palaeolithic.

\subsection{The lagoas}

The age of the lacustrine deposits that occur in interfluves on the planalto, in the south of our study region, the exact location of the lake margins (which have undoubtedly shifted over the years) and their possible taphonomic role (for example, as traps for coarser materials) are questions that need to be addressed in the future. OSL dates obtained by Dr. Gloria I. Lopez (AGE La- boratory, School of Geography \& Earth Sciences, McMaster University) for Gasparões are confined to the plough zone, unfortunately (Tab. 2). A preliminary palynological assessment of lake sediments from Gasparões, carried out by WF (above), indicates that the pollen is too abraded for full analysis. Soil chemistry analysis conducted by Dr. Alison Blyth (the Open University, UK) in the hopes of characterising the vegetation types in and around the lagoas, broadly support the palynological data.

We hypothesize that the lagoas are primarily related to minor irregularities of the regional alluvial surface (e.g. channels, levees, bars, or inundation ponds), as evidenced by the presence of Pliocene fluvial sandy deposits (15). Despite the Quaternary uplift and fluvial re-incision of that surface, large flat areas remained essentially untouched in a summital position. These areas were then exposed to wind deflation, which enhanced pre-existing topographic depressions. At Gasparões, the sandy soil profile contains clay eluviations which, together with the presence of a near-surface, relatively impermeable Miocene basement, could have promoted groundwater retention in hanging aquifers and the development of phreatic-related lakes. The position of archaeological artefacts uncovered in the sedimentary lake fill suggests that lake formation and at least part of the infill predates artefact accumulation in these features.

(15) See note 1. 


\subsection{Climate analysis}

It is possible that occupation patterns in the Sado River Basin were affected by climate change over the course of the Palaeolithic. The potential effect of aridification on human occupation patterns, for example, has been demonstrated elsewhere on the Iberian Peninsula. The abrupt coldevent of $8.2 \mathrm{Kyrs}$ ago resulted in the abandonment of low-lying regions within the Central Ebro Basin (north-eastern Spain) as people moved to higher, more humid zones (González-Sampériz et al. 2009). Observed differences in land-use during the Middle and Upper Palaeolithic in Central Portugal have been attributed to increased aridification in the inland river basins at the onset of the late glacial maximum (LGM) (Raposo 2000, 2005 contra Almeida et al. 2002). Our survey results suggest a low-density MP occupation of the study region and possible even abandonment during the early phases of the UP. Cycles of aridification, such as the one proposed for the LGM, could explain the low population densities.

To test for evidence of aridification during Late Pleistocene cold phases we used climate variables generated by the Laboratoire des Sciences du Climat et de l'Environnement (LCSE) using a coupled atmosphere-ocean general circulation model (AOGCM) to simulate "cold" and "warm" phases of MIS 3, a Heinrich event (HE) and the LGM. The HE simulation results have already been used to model aridification in the Iberian Peninsula during Heinrich Event 4 in a previous archaeological study (Sepulchre et al. 2007). The resolution of the simulation is $100 \mathrm{~km}^{2}$ and the data generated are point samples. For this analysis we sampled two points, one in the north of the Sado River Basin, near the estuary ( $\mathrm{X}=-8.357$, $\mathrm{Y}=38.513)$ and the other on its' southern margin $(\mathrm{X}=-8.357, \mathrm{Y}=37.529)$. We generated mean, minimum and maximum annual values for precipitation (PRECIP) and evapotranspiration (EVAPOT) for 20-year time series, for four time steps: MIS 3 "cold", MIS 3 "warm", H4 and LGM. We then used the mean annual precipitation and mean annual evapotranspiration values to calculate an index of aridity (AI) for each year (Tab. 3) using the formula adopted by UNEP (16)

(16) $\mathrm{AIu}=\mathrm{P} / \mathrm{PET}$, where $\mathrm{P}$ equals precipitation and PET is potential evapotranspiration. Source: UNEP 1992, World Atlas of Desertification.

\begin{tabular}{|l|c|c|c|c|}
\hline & LGM & STADE & \multicolumn{1}{|c|}{ ISTADE } & HE \\
\hline Point 1 & $0.58 \pm 0.19$ & $0.54 \pm 0.20$ & $0.70 \pm 16$ & $0.47 \pm 0.18$ \\
Point 2 & $0.38 \pm 0.12$ & $0.41 \pm 0.19$ & $0.59 \pm 0.18$ & $0.34 \pm 0.15$ \\
\hline
\end{tabular}

Tab. 3. Average aridity index (AI) values for each 20-year series. LGM = Late Glacial Maximum; $\mathrm{HE}=$ Heinrich Event.

substituting evapotranspiration (EVAPOT) for potential evapotranspiration (PET). Average AI values for MIS 3 interstadial conditions (ISTADE) are higher than average values for the stadial (STADE), Heinrich Event (HE) or last Glacial Maximum (LGM).

An analysis of variance (ANOVA) confirms that there are significant differences between the four series, for both points (17). Average AI values for the simulated, MIS 3 interstadial are higher than for any of the other climate phases, however. A second analysis of variance excluding the ISTADE, AI series indicates that there is no significant difference between the other three "cold" series. On the other hand, 2-tailed T-tests run using SPSS show that annual AI values for 20-year series are significantly different between ISTADE and any of the "cold" series.

While mean AI values for each 20-year series only indicate semi-arid (or semi-humid) conditions, according to the UNEP scale, within each series arid conditions (AI $<0.20)$ frequently arise. Point 2, the southernmost point, is the one most representative of the interior basin and likely reflects conditions in the southern half of the SRDS study region. The sample from Point 2 indicates that stadial conditions in the southern Sado River Basin were frequently arid - up to $30 \%$ of the time for the sampled time series whereas the Heinrich event results in arid conditions $20 \%$ of the time and the LGM results in arid conditions $15 \%$ of the time (Tabs. 4 and 5 ). Furthermore, arid years $(\mathrm{AI}<0.20)$ often occur consecutively during stadial phases in the sampled series, increasing their potential effect on the landscape.

Our analysis of these data, therefore, does not support an hypothesis of significant aridification in the Sado Basin at the onset of the LGM, but it does indicate periodic aridification during the cold phases of the last glacial (including the ple-

(17) Point $2(\mathrm{~F}=5.31933363, \mathrm{p}=0.002, \mathrm{df}=79)$; Point 1 $(\mathrm{F}=3.44910059, \mathrm{p}=0.020, \mathrm{df}=79)$. 


\begin{tabular}{|l|c|c|c|}
\hline & STADE02 & ISTADE & HE02 \\
\hline LGM & 0.6859 & 0.0238 & 0.4691 \\
STADE02 & & 0.0651 & 0.2936 \\
ISTADE & & & 0.0064 \\
\hline
\end{tabular}

Tab. 4. T-test results for aridity indices, comparing 20-year series for the LGM (DMG), cold MIS 3 (STADE02), "warm" MIS3 (ISTADE) and a MIS Heinrich event (HE02).

\begin{tabular}{|c|c|c|c|c|}
\hline \% Arid & LGM & STADE & ISTADE & HE \\
\hline Point 2 & 0.15 & 0.30 & 0.05 & 0.20 \\
Point 1 & 0.00 & 0.10 & 0.00 & 0.05 \\
\hline
\end{tabular}

Tab. 5. Percent of each 20-year series showing arid $(\mathrm{AI}<0.20)$ conditions. $\mathrm{LGM}=$ Late Glacial Maximum; $\mathrm{HE}=$ Heinrich Event.

niglacial) in the southern part of the study region. In other words, the southern part of the target region would have suffered arid conditions throughout the interpleniglacial and during the LGM on an episodic, annual basis. Arid conditions, especially on consecutive years, would have had a significant impact on the distribution of vegetation and therefore of prey species. Ultimately, this would have affected human settlement patterns. The data series for point 1 indicates that conditions near the mouth of the Sado River would have been relatively milder - at worst, semi-arid at times when the southern Sado River Basin (represented by point 2) would have been arid. This means that Neanderthal populations living in the interior basin could have been drawn to the coast during cold intervals. Furthermore, during the LGM coastal regions beyond the Sado River estuary may have been relatively more productive (Bicho and Haws 2008) thus reinforcing an existing trend.

\subsection{Chronology of occupation of the Sado River Basin}

Since all of the sites and localities identified during this research are surface deposits, it is not possible to establish a chronological framework for the occupation of the Sado River Basin on any basis other than typological. Typologically, the two largest Mousterian assemblages (Moínhos 1 and Mina do Paço) share affinities with late MP assemblages described elsewhere in Portugal (18) (see above). The distribution of Middle Palaeolithic sites and localities in the southern part of the study region suggests the occupation of river terraces along the Sado and several of its tributaries, notably the Roxo River (which lies between two major jasper outcrops at Moínhos and Mina do Paço) as well as occupation of the planalto (the southern Alentejo plain) in the vicinity of either jasper outcrops or of the small, seasonal lakes that we believe were formed during the Pleistocene. These lakes, located on the planalto in interfluvial zones, may have attracted game (and their predators).

Of 18 locations containing MP material, 6 are designated as sites/localities (all of which occur in the southern part of the study region) and the remainder are designated as lithic scatters. Our results, therefore, suggest that the southern part of the Sado River Basin was sparsely populated during the Middle Palaeolithic, possibly as a result of aridification during cold phases of the Late Pleistocene. The pattern of occupation of the southern part of the Sado River Basin during the MP is focussed on jasper outcrops, small seasonal lakes on the planalto and river terraces on the right bank of the Sado River and its tributaries. Upper Palaeolithic finds are remarkable for their scarcity. Only $\mathrm{N}=8$ isolated lithic finds diagnostic of the UP (and a further $\mathrm{N}=8$ laminar pieces) are reported here; $50 \%$ of these are made of flint - presumably imported since no local sources are known $(37.5 \%$ if one includes the blades). None of the jasper quarries (e.g., Moínhos, Mina do Paço, Brejo, Alamo) appears to have been used during the UP. This apparent hiatus in the history of the Palaeolithic occupation of the Sado River Basin warrants further analysis. A similar "gap" in the archaeological record of Central Portugal at the beginning of the UP - there are 5 sites that could be Aurignacian in age - has lead to the suggestion that erosion events occurring during MIS 3 and at the LGM may have created hiatuses in the archaeological record (Aubry 2008; Bicho 2000). Similar events could hypothetically have occurred in the Sado River Basin, creating the pattern observed above. If that were the case, however, the destruction of UP sites should have resulted in the deposition of at least some UP materials in the river valleys, as Aubry (2008) points

(18) See note 7. 
out. Surveys along the Sado River and several of its tributaries, such as the Ribeira do Pero Bonito and Ribeira do Roxo, in the vicinity of São João, yielded sizeable, mixed assemblages of lithic and ceramic material, including Chalcolithic and Neolithic artefacts, but very little material diagnostic of the UP. Furthermore, although the river terraces are obviously affected by erosion, the planalto is a broad, essentially flat surface that has not been substantially altered since the formation of the existing hydrological system by sharp downcutting during the Pleistocene (19). Flow accumulation rates on the planalto, mapped using arcGIS, indicate the prevalence of low flow rates.

Our results, therefore, suggest that the southern half of the Sado River Basin was extremely sparsely populated (and possibly even abandoned) during the Upper Palaeolithic. This could be due to the combined effect of aridification during the LGM and the increased productivity of coastal regions drawing populations from the interior of the Sado Basin (Bicho and Haws 2008). Alternatively, the focus of settlement may have shifted from sedimentary river basins to secondary river valleys and peripheral massifs during the UP, as proposed for the Tagus River Basin (Raposo 2000). Our survey focused on low altitude settings within the Sado River Basin and this may have prevented us from detecting the proposed shift in land-use patterns. We also surveyed the massifs that form the western and southern margins of the basin (the Serra Grândola and the Serra da Vigia) however, and none of these higher altitude surveys yielded archaeological results. The lack of human occupation of the massifs bordering the southern half of the Sado River Basin could result from a combination of the lack of suitable raw materials and the composition of the bedrock, which consists primarily of schists (which do not form rockhelters) rather than survey design, therefore.

\section{CONCLUSION}

Results of the SRDS survey suggest that Neanderthals occupied the Sado River Basin at low population densities, possibly intermittently. The distribution of Middle Palaeolithic sites and

(19) See note 2. localities in the southern part of the study region suggests the occupation of river terraces along the Sado and several of its tributaries, notably the Roxo River (which lies between two major jasper outcrops at Moínhos and Mina do Paço) as well as occupation of the planalto (the southern Alentejo plain) in the vicinity of either jasper outcrops or of the small, seasonal lakes that we believe were formed during the Pleistocene. These lakes, located on the planalto in interfluvial zones, may have attracted game (and their predators).

The main concentration of MP archaeological finds occurs in the southern half of the Sado River Basin, on the planalto between the two most visually prominent raw material sources (Moínhos and Mina do Paços). These jasper outcrops are intervisible and several small lakes, or lagoas (including the site of Gasparões), dot the landscape between them. Movement between the outcrops and to and from the lagoas and nearby river terraces would have been relatively easy as indicated by a cost surface analysis. Ease of travel and the presence of readily identifiable landmarks (which also constituted points of interest, i.e., sources of valuable raw material) make this part of southern Alentejo a particularly "legible" landscape (Burke 2006) - and therefore a relatively attractive one.

When arid conditions set in intermittently during cold phases of MIS3 and during the LGM in the interior of the Sado River Basin, Neanderthal populations likely voted with their feet,- either retreating to higher altitudes or to coastal regions (Raposo 2005). If climate change induced a shift in the spatial distribution of Neanderthals occupying the Sado River Basin, as our data indicate, this, in turn, may have caused a shift in subsistence patterns including increased use of coastal resources. Unfortunately, the sedimentary history of the northern part of the study region creates difficult conditions for survey and we were unable to test an hypothesis of population contraction towards the litoral zone, much less our speculations about subsistence. Coastal resources are known to have been exploited during the Middle Palaeolithic in Portugal, however, e.g. at Figueira Brava (Antunes 2000) a site located in the Serra Arrábida near the Sado River estuary, as well as at Gibraltar (Stringer et al. 2008). Hypothetically, again, a broader spectrum diet, i.e., one including coastal resources, could even explain the persistence of Neanderthal populations on the fringe of 
the Iberian Peninsula (Finlayson 2008) - though the existing faunal data do not indicate intensive use of these resources (Klein and Steele 2008).

A similar argument can be made to explain evidence of a hiatus in the archaeological record of the interior Sado River Basin during the LGM. The absence of a significant Upper Palaeolithic presence in the target region - potentially attributable to local aridification during the LGM needs to be further investigated, but the lack of Upper Palaeolithic materials in secondary deposits along the river beds reinforces the argument for an occupational hiatus. The littoral zone of Portugal became relatively more productive during the LGM (Bicho and Haws 2008) and, as sea level dropped and the littoral zone expanded, would have provided humans with more habitat (Bailey and Flemming 2008). Coastal zones, including the estuary of the Sado River, therefore, could have been the main focus of human occupation in southern Alentejo during the Upper Palaeolithic.

Taken in conjunction with paleoclimate simulations for MIS 3 and the LGM, the archaeological data resulting from this survey suggest episodic occupation of the Sado River Basin during the Middle Palaeolithic with phases of abandonment (or near abandonment, with no archaeological visibility) occurring during cold phases of MIS 3, driven by a process of aridification. If the study region was occupied at all during the Upper Palaeolithic, it must have been during one of these low density phases and is not (as yet) archaeologically visible. It isn't until the end of the Palaeolithic that the archaeological record indicates that the Sado River Basin was repopulated and, during the Mesolithic, that a year-round presence is documented (Bicho 1994).

\section{ACKNOWLEDGEMENTS}

Funding for this research was provided by the Social Sciences and Humanities Research Council of Canada. The authors are indebted to Prof. Nuno Bicho (U. do Algarve) who provided invaluable assistance, especially during the initial phases of the project. We would also like to acknowledge the material support offered to the project by the regional offices of IGESPAR at Campo Verde (Alentejo) with special thanks to Dr. Manuela de Deus. The Câmara Municipal de
Aljustrel generously provided us with accomodation in 2007 and 2008, with special thanks to Dr. Carlos Pedro. The Muséo de Aljustrel was instrumental in supporting the project and is curating the SRDS collections, with thanks to Dr. Artur Martins. Dr. Adrian Burke (Université de Montréal) provided invaluable geoarchaeological expertise in the field for two consecutive field seasons and analysed the chemical composition of the jaspers from Moinhos 1 and Mina do Paço (see note 8). Original illustrative plates are the work of M. Fernanda da Sousa. Initial description of the lithic assemblage from Mina do Paço was done by Gaëtan Lebret (Université de Montréal). Technical assistance with the arcGIS database was provided by Louis Gilbert (Université de Montréal). Fieldwork was conducted with the help of several people over the years, including: Dr. Adrian Burke (Université de Montréal), Dr. Nelson Almeida (IGESPAR), Dr. Gloria Lopez and Dr. Jack Rink (McMaster University), Maria Salvador, Mrs. Marilyn Steely, Jorge Correios, Frédérick Hottin, Joanna da Silva, Caterina Mendosa da Silva, and Hugo de Bolle Verissimo.

\section{BIBLIOGRAPHY}

Aguirre, E. y Carbonell, E. 2001: "Early human expansions into Eurasia: The Atapuerca evidence". Quaternary International 75 (1): 11-18.

Almeida, F.; Araújo, A. C. and Ribeiro, P. C. 2002: "Contribuiçao para o estudo do Paleolítico no Alentejo interior. Resultados Preliminares do Bloco B1 do Plano de Minimizaçao de Impactes da Barragem de Alqueva". Al-Madan IIa serie (11): 94-98.

Almeida, M.; Dimuccio, L. A.; Aubry, T.; Neves, M. J. and Cunha, L. 2006: "Enquadramento geomorfológico e crono-cultural do sítio arqueológico de Gândara do Outil 1". Publicações da Associação Portuguesa de Geomorfólogos 3 (APGeom): 205210.

Almeida, N. 2003: "Pré-história antiga no nordeste Alentejano". Ibn Maruan 12: 185-197.

Angelucci, D. and Zilhão, J. 2009: "Stratigraphy and Formation Processes of the Upper Pleistocene Deposit at Gruta da Oliveira, Almonda Karstic System, Torres Novas, Portugal". Geoarchaeology 24 (3): 277-310.

Antunes, M. T. 1990-1991: "O Homem da Gruta da Figueira Brava (ca. 30000 BP). Contexto ecológico, alimentação, canibalismo". Memórias da Academia das Ciências de Lisboa XXXI: 487-536. 
Antunes, M. T. (ed.) 2000: Colóquio 'Ultimos Neandertais em Portugal: evidencia, odontologica e outra' (enero 1999). Academia das Ciências de Lisboa. Lisboa.

Antunes, M. T. and Cunha, A. S. 1992: "Neanderthalian Remains from Figueira Brava Cave, Portugal". Geobios 25 (5): 681-692.

Araújo, A. C. and Almeida, F. 2003: "Barca do Xarez de Baixo: balanço de quatro anos de trabalhos arqueológicos". Revista portuguesa de arqueologia 6,1: 17-67.

Araújo, A. C. and Lejeune, M. 1995: Gruta do Escoural: Necrópole Neolítica e Arte Rupestre Paleolitica. Instituto Português do Património Arquitectónico e Arqueológico. Lisboa.

Arrizabalaga, A.; Altuna, J.; Areso, P.; Elorza, M.; García, M.; Iriarte, M. J.; Mariekurrena, K.; Mujika, J. and Peman, E. 2003: "The initial Upper Paleolithic in Northern Iberia: New evidence from Labeko Koba". Current Anthropology 44 (3): 413-421.

Aubry, T. 2008: “Caractérisation et discontinuités des registres pedosédimentaires de l'occident Péninsulaire entre 30.000 et $10.000 \mathrm{BP}$ : implication sur l'interprétation archéologique". In T. Aubry, F. Almeida, A. C. Araujo and M. Tiffagom (eds.): Space and Time: Which Diachronies, Which Synchronies, Which Scales? / Typology vs Technology. British Archaeological Reports, International Series S1831, Archaeopress. Oxford: 9-21.

Aubry, T.; Almeida, F. and Neves, M. J. 2006: “The Middle-to-Upper Paleolithic transition in Portugal: an Aurignacian phase or not?". Trabalhos de Arqueologia 45: 93-110.

Bailey, G. N. and Flemming, N. C. 2008: "Archaeology of the continental shelf: Marine resources, submerged landscapes and underwater archaeology". Quaternary Science Reviews 27 (23-24): 2153-2165.

Bermúdez de Castro, J. M.; Arsuaga, J. L.; Carbonell, E.; Rosas, A.; Martínez, I. and Mosquera, M. 1997: "A hominid from the lower Pleistocene of Atapuerca, Spain: Possible ancestor to Neanderthals and modern humans". Science 276 (5317): 1392-1395.

Bermúdez de Castro, J. M.; Martinón-Torres, M.; Carbonell, E.; Sarmiento, S.; Rosas, A.; Made, J. van der and Lozano, M. 2004: "The Atapuerca sites and their contribution to the knowledge of human evolution in Europe". Evolutionary Anthropology: Issues, News, and Reviews 13 (1): 25-41.

Bicho, N. F. 1994: "The end of the Palaeolithic and the Mesolithic in Portugal". Current Anthropology 35: 664-674.

Bicho, N. F. 2000: "Revisão critica dos conhecimentos actuais do Paleolitico Superior Portugues". Congresso de arqueologia Peninsular (Vila Real,
1999), II Paleolitico da Peninsula Iberica: 425-442. Porto.

Bicho, N. F. 2004: "The Middle Paleolithic occupation of southern Portugal". In N. J. Conard (ed.): Settlement Dynamics of the Middle Paleolithic and Middle Stone Age, II. Kerns Verlag. Tubingen: 513-531.

Bicho, N. and Haws, J. 2008: “At the land's end: marine resources and the importance of fluctuations in the coastline in the prehistoric hunter-gatherer economy of Portugal". Quaternary Science Reviews 27: 2166-2175.

Boëda, E., 1994: Le Concept Levallois: variabilité des méthodes. Monographie du Centre de recherches archéologiques 9. Editions du CNRS. Paris.

Bordes, F. 1961: Typologie du Paléolithique Ancien et Moyen. Editions du CNRS. Paris.

Breuil, H.; Ribeiro, O. and Zbyszewski, G. 1943: "Les plages quaternaires et les industries préhistoriques du litoral d'Alentejo entre Sines et Vila Nova de Milfontes". IV Congresso luso-espanhol para o progresso das ciências (Porto 1942). Porto.

Breuil, H. and Zbyszewski, G. 1949: "Contribution à l'étude des industries paléolithiques des plages quaternaires de l'Alentejo littoral'. Comunicações dos Serviços Geológicos de Portugal 27: 1-68.

Bridgland, D. R.; Antoine, P.; Limondin-Lozouet, N.; Santisteban, J. I.; Westaway, R. and White, M. J. 2006: "The Palaeolithic occupation of Europe as revealed by evidence from the rivers: data from IGCP 449". Journal of Quaternary Science 21 (5): 437-455.

Burke, A. 2006: "Neanderthal settlement patterns in Crimea: a landscape approach". Journal of Anthropological Archaeology 25 (4): 510-523.

Cabrera, V.; Maíllo, J. M.; Lloret, M. y Bernaldo de Quirós, F. 2001: "La transition vers le Paleolithique superieur dans la grotte du Castillo (Cantabrie, Espagne): la couche 18'. L'Anthropologie 105: 505532.

Carbonell, E.; Bermúdez de Castro, J. M.; Arsuaga, J. L.; Díez, J. C.; Rosas, A.; Cuencabescos, G.; Sala, R.; Mosquera, M. and Rodríguez, X. P. 1995: "Lower Pleistocene Hominids and Artifacts from Atapuerca-Td6 (Spain)". Science 269 (5225): 826-830.

Carbonell, E.; Bermúdez de Castro, J. M.; Pares, J. M.; Pérez-González, A.; Cuenca-Bescos, G.; Olle, A.; Mosquera, M.; Huguet, R.; Made, J. van der; Rosas, A.; Sala, R.; Vallverdu, J.; García, N.; Granger, D. E.; Martinon-Torres, M.; Rodríguez, X. P.; Stock, G. M.; Verges, J. M.; Allue, E.; Burjachs, F.; Cáceres, I.; Canals, A.; Benito, A.; Díez, C.; Lozano, M.; Mateos, A.; Navazo, M.; Rodríguez, J.; Rosell, J. and Arsuaga, J. L. 2008: "The first hominin of Europe". Nature 452 (7186): 465-469. 
Debénath, A. and Dibble, H. 1994: Handbook of Paleolithic Typology. 1 Lower and Middle Paleolithic of Europe. University of Pennsylvania. Philadelphia.

Duarte, C.; Mauricio, J.; Pettitt, P. B.; Souto, P.; Trinkaus, E.; Plicht, H. van der and Zilhão, J. 1999: "The early Upper Paleolithic human skeleton from the Abrigo do Lagar Velho (Portugal) and modern human emergence in Iberia". Proceedings of the National Academy of Sciences of the United States of America 96 (13): 7604-7609.

Falguères, C.; Bahain, J. J.; Yokoyama, Y.; Arsuaga, J. L.; Bermúdez de Castro, J. M.; Carbonell, E.; Bischoff, J. L. and Dolo, J. M. 1999: "Earliest humans in Europe: the age of TD6 Gran Dolina, Atapuerca, Spain". Journal of Human Evolution 37 (3): 343-352.

Ferring, C. R.; Lindly, J.; Bicho, N. F. and Stiner, M. 2000: "The Middle Paleolithic of Algarve". Congresso de arqueologia Peninsular (Vila Real, 1999), II Paleolitico da Peninsula Iberica: 271-276. Porto.

Finlayson, C. 2008: "On the importance of coastal areas in the survival of Neanderthal populations during the Late Pleistocene". Quaternary Science Reviews 27 (23-24): 2246-2252.

Finlayson, C.; Giles Pacheco, F.; Rodríguez-Vidal, J.; Darren A. Fa; Gutiérrez López, J. M.; Santiago Pérez, A.; Finlayson, G.; Allue, E.; Baena Preysler, J.; Cáceres, I.; Carrión, J. S.; Fernández Jalvo, Y.; Gleed-Owen, Ch. P.; Jiménez Espejo, F. J.; López, P.; López Sáez, J. A.; Riquelme Cantal, J. A.; Sánchez Marco, A.; Giles Guzman, F.; Brown, K.; Fuentes, N.; Valarino, C. A. M.; Villalpando, A.; Stringer, Ch. B.; Martínez Ruiz, F. and Sakamoto, T. 2006: "Late survival of Neanderthals at the southernmost extreme of Europe". Nature 443 (7113): 850-853.

Forenbaher, S. 1998: "Production and exchange during the Portuguese Chalcolithic. The case of bifacial flaked stone industries". Trabajos de Prehistoria 55 (2): 55-71.

González-Sampériz, P.; Utrilla, P.; Mazo, C.; Valero-Garcés, B.; Sopena, M. C.; Morellón, M.; Sebastián, M.; Moreno, A. y Martínez-Bea, M. 2009: "Patterns of human occupation during the early Holocene in the Central Ebro Basin (NE Spain) in response to the 8.2 ka climatic event". Quaternary Research 71 (2): 121-132.

Hublin, J. J. 1992: "Recent human evolution in northwestern Africa". Philosophical Transactions: Biological Sciences 337 (1280): 185-191.

Klein, R. G. and Steele, T. E. 2008: "Gibraltar data are too sparse to inform on Neanderthal exploitation of coastal resources". Proceedings of the National Academy of Sciences 105 (51): E115.
Maíllo Fernández, J. M.; Cabrera-Valdés, V. y Bernaldo de Quirós, F. 2004: "Le débitage lamellaire dans le Moustérien final de Cantabrie (Espagne): le cas de El Castillo et Cueva Morin". L'Anthropologie 108 (3-4): 367-393.

Mellars, P. (ed.) 1996. The Neanderthal legacy. Princeton Press. Princeton.

Mozzi, P.; Azevedo, M. T.; Nunes, E. and Raposo, L. 2000: "Middle terrace deposits of the Tagus river in Alpiarça, Portugal, in relation to early human occupation". Quaternary Research 54 (3): 359-371.

Oliveira, J. T. 1984. Carta Geológica de Portugal: Noticia explicativa da Folha 7. Serviços Geológicos de Portugal, Lisboa.

Pimentel, N. and Azevedo, T. M. 1991: "Evolution Plio-quaternaire du secteur méridional du Bassin du Sado (Bas-Alentejo, Portugal)". Comunicações dos Serviços Geológicos de Portugal 77: 121-132.

Raposo, L. 1995: “Ambientes, territorios y subsistencia en el Paleolítico Medio de Portugal". Complutum 6: 57-77.

Raposo, L. 2000: “The Middle-Upper Palaeolithic Transition in Portugal". In C. B. Stringer, R. N. E. Barton and J. C. Finlayson (ed.): Neanderthals on the Edge. Oxbow Books. Exeter: 95-109.

Raposo, L. 2005: "Paleolítico Medio y Neandertales en la fachada occidental ibérica". En E. Badequano (ed.): El universo Neanderthal I. Fundación Duques de Soria. Soria: 13-70.

Raposo, L. and Cardoso, J. L. 1998: "Las industrias líticas de la Gruta Nova da Columbeira (Bombarral, Portugal) en el contexto del Musteriense final de la Península Ibérica". Trabajos de Prehistoria 55 (1): $39-62$.

Raposo, L.; Salvador, M. and Pereira, J. P. 1993: “O Acheulense no vale do Tejo, em territorio Portugues". Arqueologia e Historia 10 (3): 3-29.

Raposo, L. and Santonja, M. 1995: "The Earliest Occupation of Europe: The Iberian Peninsula". In W. Roebroeks and T. V. Kolfschoten (ed.): The Earliest Occupation of Europe. University of Leiden. Leiden: 7-25.

Roebroeks, W.; Conard, N. J. and Kolfschoten, T. van 1992: "Dense forests, cold steppes, and the Palaeolithic settlement of northern Europe". Current Anthropology 33 (5): 551-586.

Schermerhorn, L. J. G.; Zbyszewski, G. and Veiga Ferreira, O. 1987: Noticia explicative da folha 42-D Aljustrel. Serviços Geológicos de Portugal. Lisboa.

Sepulchre, P., Ramstein, G.; Kageyama, M.; Vanhaeren, M.; Krinner, G.; Sánchez-Goñi, M. F. and D’Errico, F. 2007: "H4 abrupt event and late Neanderthal presence in Iberia". Earth and Planetary Science Letters 258 (1-2): 283-292.

Serangeli, J. and Bolus, M. 2008: "Out of Europe The dispersal of a successful European hominin form". Quartar 55: 83-98. 
Straus, L. G. 1997: "The Iberian situation between 40,000 and 30,000 B.P. in light of European models of migration and convergence". In G. A. Clark and C. M. Willermet (ed.): Conceptual Issues in Modern Human Origins Research (Evolutionary foundations...). Aldine de Gruyter. New York: 235-252.

Straus, L. G. 2001: "Africa and Iberia in the Pleistocene". Quaternary International 75: 91-102.

Straus, L. G.; Bicho, N. and Winegardner, A. C. 2000. "The Upper Palaeolithic settlement of Iberia: first-generation maps". Antiquity 74: 553-366.

Stringer, C. B.; Finlayson, J. C.; Barton, R. N. E.; Fernández-Jalvo, Y.; Cáceres, I.; Sabin, R. C.; Rhodes, E. J.; Currant, A. P.; Rodríguez-Vidal, J.; Giles-Pacheco, F. and Riquelme-Cantal, J. A. 2008: "Neanderthal exploitation of marine mammals in Gibraltar". Proceedings of the National Academy of Sciences 105 (38): 14319-14324.

Tattersall, I. and Schwartz, J. H. 1999: "Hominids and hybrids: The place of Neanderthals in human evolution". Proceedings of the National Academy of Sciences of the United States of America 96 (13): 7117-7119.

Viana, A. 1943: "Paleolítico no Baixo-Alentejo". IV Congresso luso-espanhol para o progresso das ciências (Porto, 1942): 5-21. Porto.

Viana, A. 1945: "Paleolítico do Baixo Alentejo: Vale do Guadiana". Brotéria 40 (2): 192 -211.

Viana, A. 1946: "Paleolitico das margens do Guadiana". Arquivo de Beja 3: 364-441.

Viana, A. 1947: "Paleolítico dos arredores de Beja e do Litoral Algarvio - Zona de Sotavento". Brotéria 45 (1): 45-57.

Viana, A. and Zbyszewski, G. 1949: "Indústria paleolítica de Ficalho (Baixo Alentejo)". Trabalhos de Antropologia e Etnologia (Nova Série) 12, 1: 169-172.
Viana, A. and Zbyszewski, G. 1952: "Paleolítico dos arredores de Beja". Comunicações dos Serviços Geológicos e Mineiros 33: 1-56.

Villaverde, V.; Aura, J. E. and Barton, C. M. 1998: "The Upper Paleolithic in Mediterranean Spain: A Review of Current Evidence". Journal of World Prehistory 12 (2): 121-198.

Zbyszewski, G. 1971: Carta Geologica do Quaternario de Portugal na escala de 1/1 000 000: notícia explicativa. Serviços Geológicos de Portugal. Lisboa.

Zilhão, J. 1997: "The Ebro frontier and the extinction of Neandertals". Journal of Human Evolution 32 (4): A25-A26.

Zilhão, J. 1998: "The extinction of Iberian Neandertals and its implications for the origins of modern humans in Europe". Mediterranean Prehistory Online 22 de Dezembro 1998?

Zilhão, J. 2006: "Chronostratigraphy of the Middle-to-Upper Paleolithic Transition in the Iberian Peninsula". Pyrenae 37 (1): 7-84.

Zilhão, J.; Davis, S. J.; Duarte, C.; Soares, A. M. M.; Steier, P. and Wild, E. 2010: "Pego do Diabo (Loures, Portugal): dating the emergence of anatomical modernity in westernmost Eurasia". PloS ONE 5 (1): e8880.doi:10.1371/journal.pone.0008880

Zilhão, J.; Marks, A. E.; Ferring, C. R.; Bicho, N. F. and Figueiral, I. 1995: "The Upper Paleolithic of the Rio Maior Basin (Portugal). Preliminary results of a 1987-1993 Portuguese-American research project". Trabalhos de Antropologia e Etnologia 35 (4): 69-82.

Zilhão, J. and Villaverde, V. 2008: "The Middle Paleolithic of Murcia". Treballs d'Arqueologia 14: 229-248. 